\author{
MINERALOGIA POLONICA \\ 10.2478/v10002-007-0004-y \\ PL ISSN 0032-6267 \\ Vol. 37, No 1, 2006
}

Pawet BYLINA ${ }^{1}$

\title{
LOW-GRADE METAMORPHISM OF PERMIAN MAFIC ROCKS FROM THE GORZÓW WIELKOPOLSKI BLOCK (FORE SUDETIC MONOCLINE, NW POLAND): AGE AND MECHANISM
}

\author{
Received 3 February 2006; accepted 14 April 2006
}

A b st r a ct. The metavolcanic rocks in the Gorzów Wielkopolski area (NW Poland) are andesite-basalts and andesites derived from contaminated within-plate subalkaline basalt melts. K-Ar dating of primary $\mathrm{K}$-feldspar yields an extrusion age of $285 \pm 5 \mathrm{Ma}$. This new date suggests that these rocks may be the youngest dated Permo-Carboniferous volcanic rocks within the eastern margin of the North German Basin.

Petrological and micro-thermometric data indicate that the volcanic rocks were altered by a sub-greenschist facies, metamorphic process that proceeded within temperatures and pressures ranging from $195-290^{\circ} \mathrm{C}$ and $63-96 \mathrm{MPa}$, respectively. The major metamorphic phases, corrensite, pumpellyite, laumontite and prehnite, formed due to interaction between the original volcanic rock and low-saline $\mathrm{Na}_{2} \mathrm{SO}_{4}$-rich hydrothermal fluids. Numerical modelling indicates fluid flow in fractures as the most probable explanation for the low-grade hydrothermal metamorphism. Model calculations suggest that the process was of short duration, ca 140-250 years. K-Ar dating reveals three Mesozoic episodes at 121 $\pm 2 \mathrm{Ma}, 188-190 \mathrm{Ma}$ and $149 \pm 4 \mathrm{Ma}$ that can be ascribed to the metamorphism. These ages are similar to previously determined Mesozoic ages from altered volcanic- and clastic rocks in the North German Basin and in the Polish Basin.

Key-words: K-Ar dating, hydrothermal metamorphism, metavolcanic rocks, Polish Basin, North German Basin, Mesozoic hydrothermal activity

\section{INTRODUCTION}

Mafic igneous rocks are useful as indicators of geodynamic setting. However, they are extremely sensitive to chemical changes during metamorphism. In particular, low-grade metamorphism associated with influx of large volumes of hydrothermal fluids will modify chemical and mineral compositions. Under low-grade metamorphic conditions, equilibrium may not be attained and metastable phases may form and persist. Rough estimates only of metamorphic environment may be determined from

1 Institute of Geological Sciences, Polish Academy of Sciences, ul. Twarda 51/55, 00-818 Warszawa, Poland; bylina@twarda.pan.pl 
theoretical equilibrium-based models (e.g., Carr et al. 1999). Nevertheless, stability relationships of the main metamorphic minerals based on experimental and theoretical studies, combined with measured parameters from natural systems, should provide realistic estimations of the metamorphic conditions.

The focus of this paper is threefold. It investigates the age of Rotliegend metavolcanic rocks from boreholes located in the vicinity of Gorzów Wielkopolski, NW Poland, the P-T conditions of their metamorphism and the reasons for the unusual alteration process they record.

\section{GEOLOGICAL SETTING}

The Central European Basin System (CEBS) extends from the southern part of the North Sea through the Netherlands, Denmark, and northern Germany to Poland. The CEBS comprises three major basins: 1) the Norwegian-Dutch Basin, 2) the North German Basin and 3) the Polish Basin (e.g., Scheck-Wenderoth, Lamarche 2005). The development of the CEBS began during the Late Carboniferous within the framework of dextral transtension and transpression associated with the westward movement of Gondwana with respect to Laurasia following the Variscan continent to continent collision (e.g., Ziegler 2005). Initial rifting was associated with volcanic activity and followed by post-rift thermal subsidence and deposition of the Rotliegend clastics and of the Late Permian Zechstein evaporitic sequences (e.g., Dadlez et al. 1995; Scheck, Bayer 1999; Stephenson et al. 2003). Later subsidence during Triassic to mid-Jurassic times was related to the development of the North Sea rift. In the North German Basin resumed tectonic activity in a transtensional regime resulted in subsidence along its south-western margin in latest Jurassic/earliest Cretaceous times (e.g., Mazur et al. 2005; Scheck, Bayer 1999). The Senonian pulse of intraplate compression started during the Late Cretaceous - Palaeocene tectonic inversion which affected the Mid Polish Trough as well as the other parts of the CEBS (e.g., Mazur et al. 2005; Ziegler 2005).

The Polish Basin experienced gradual thermal subsidence from the Late Permian to the Late Cretaceous (Dadlez et al. 1995; Stephenson et al. 2003). The Mid-Polish Trough dominated the regional subsidence pattern during the entire Mesozoic. Salt movements, initiated in the early Triassic, locally modified the subsidence pattern (Krzywiec 2004). Thick Zechstein salt formations controlled tectonic activity by mechanically decoupling the pre-Zechstein basement from the overlying sedimentary cover.

Over the past decades, the CEBS, including the Polish Basin, has been extensively explored due to its economically important hydrocarbon resources (e.g., Czechowski, Piela 1997; Herman, Mamczur 1986; Karnkowski 1999). The NW part of Polish Basin holds many gas and oil deposits, e.g., the largest Polish deposit, Barnówko-Mostno-Buszewo. The basin is the most promising oil-and-gas prospecting area within the Polish Lowlands. The principal gas and oil reservoirs are carbonate reef formations of the Zechstein Limestone and Main Dolomite. The main gas-bearing formations are the Rotliegend sandstones and reef-type formations of the Zechstein Limestone (for details, see Karnkowski 1999). 


\section{Permo-Carboniferous volcanic activity}

The Permo-Carboniferous volcanic rocks in the pre-Zechstein basement of N Germany and NW Poland originated during the initial phase of the evolution of the CEBS. The thickness of the CEBS volcanic complex is over 2500 m (Fig. 1; Plein 1993; Paulick, Breitkreuz 2005). The Central European Basin igneous province comprises approximately 70,000-80,000 km³ of volcanogenic rocks (e.g., Plein 1993; Paulick, Breitkreuz 2005). On the basis of petrological and geochemical studies, Benek et al. (1996) recognized five stages of Permo-Carboniferous volcanic activity in the German part of the CEBS: 1) an Upper Carboniferous (Stefanian) andesite stage, 2) a Lower Rotliegend ignimbrite stage, 3) an effusive post-ignimbrite stage, 4) a late rhyolite stage and 5) an Upper Rotliegend late basalt stage. The Permo-Carboniferous volcanic rocks in NE Germany consist dominantly of rhyolites, ignimbrites, and andesites as well as minor basalts, both tholeiitic and alkali varieties. SHRIMP dating of volcanic zircon grains indicate that the rocks were extruded between 302-294 Ma (Fig. 2 and Breitkreuz, Kennedy 1999) over a time span of ca 10 Ma. The volcanic rocks were extruded in a subaeral environment under moderate to semi-arid climatic conditions (Schneider, Gebhardt 1993). They are associated with alluvial to lacustrine sediments (e.g., Rieke et al. 2003). The volcanic and volcanoclastic rocks in the German part of the CEBS usually cover folded clastic rocks of the Variscan orogen or its foreland (McCann 1996).

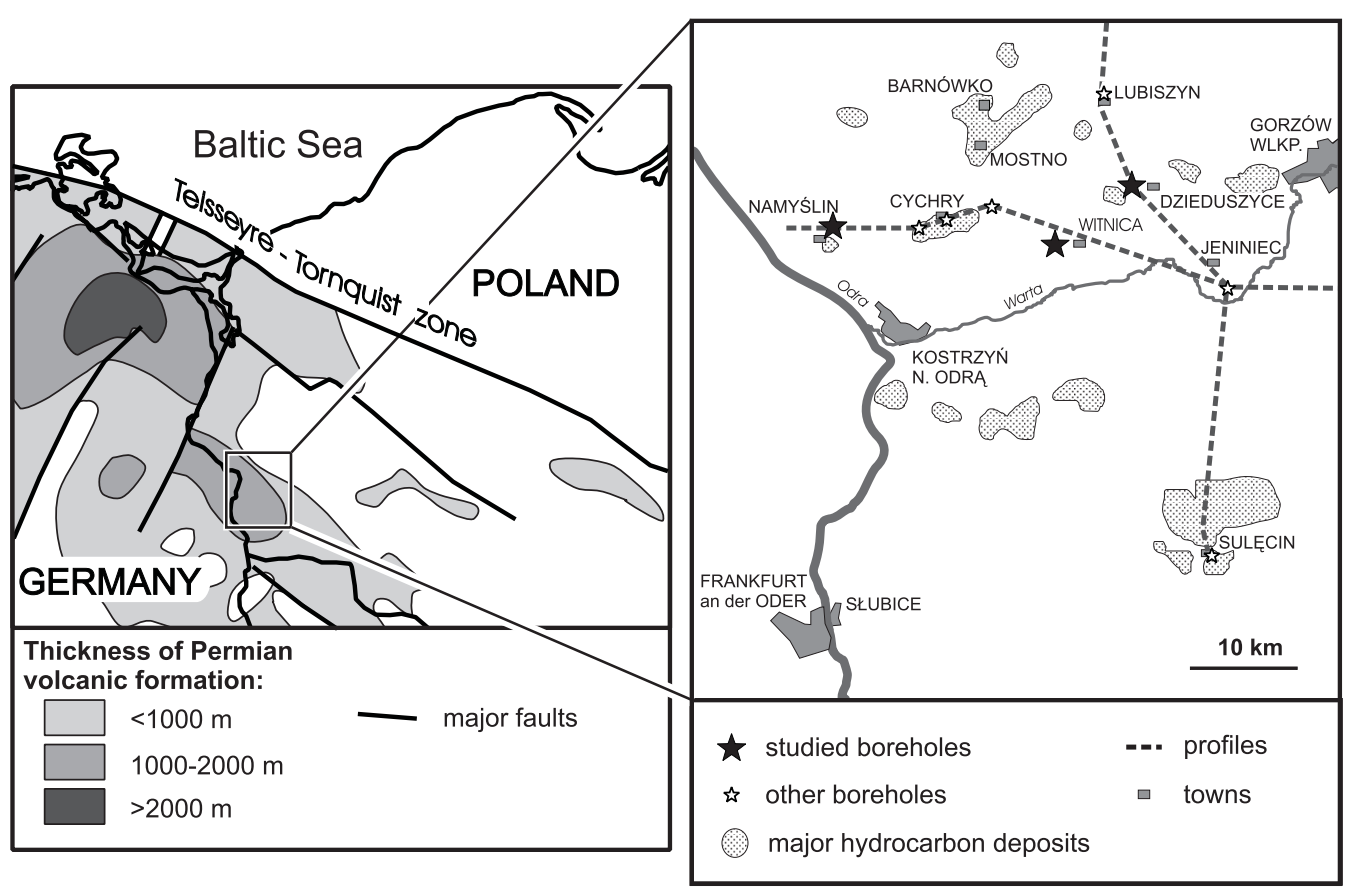

Fig. 1. Distribution of Early Permian volcanic formations (left, modified after Plein 1993) and sketch map with positions of boreholes sampled and cross-section lines (right); location of hydrocarbon deposits after Buniak (2004) 


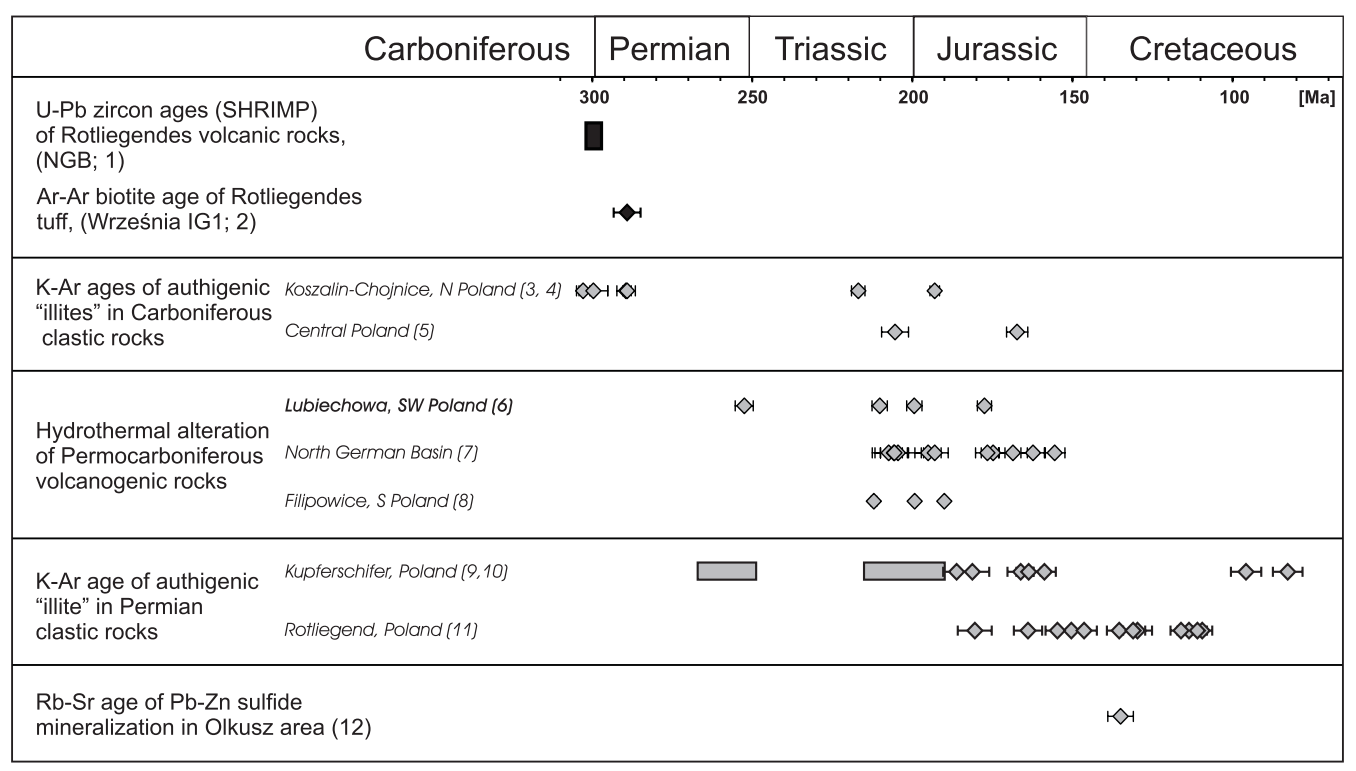

Fig. 2. Compilation of radiometric ages of mineral-forming events from North German and Polish Basins. Diamonds denote single-data points (with error bars, if available). Rectangles denote age ranges. Black filling - volcanic event. Gray filling - alteration or diagenetic ages.

Sources: 1 - North German Basin volcanic rocks, Breitkreuz and Kennedy (1999); 2 - Permian tuff, Września IG-1, Lippolt et al. (1982); 3 - Carboniferous (Dinantian) black shale, Kołobrzeg-Chojnice zone, Górniak et al., (2004); 4 - Carboniferous (Dinantian) tuff, Kołobrzeg-Chojnice zone, Protas (2004); 5 - Carboniferous sandstones, Warsaw vicinity, Kozłowska and Poprawa (2004); 6 - altered volcanic rock from Lubiechowa, Sudetes, Michalik et al. (2003); 7 - secondary mineralization in basic and intermediate volcanic rocks, North German Basin, Brecht (1999); 8 - Permian tuff from Filipowice, Cracow viscinity, Michalik et al. (2004), Michalik, (pers. comm.); 9 - Permian Kupferschifer shale (gray rectangles), Bechtel et al. (1999); 10 - Permian Weissliegend sandstone, Michalik (2001); 11 - Permian Rotliegend clastic rocks, Wielkopolska region, Maliszewska (1997); $12-\mathrm{Pb}-\mathrm{Zn}$ ores, Olkusz region, Heijlen et al. (2003)

At present, a complex of sediments up to $6 \mathrm{~km}$ thick covers most of the Permo-Carboniferous volcanic rocks (e.g., Paulick, Breitkreuz 2005).

The Permo-Carboniferous volcanic rocks in Poland occur in three regions: 1) the NW Polish Basin (Ryka 1981; Jackowicz 1995; Maliszewska et al. 2003; Sadowski, Madej 2001; Dubińska et al. 2004a), 2) the Małopolska region (e.g., Czerny, Muszyński 1997, 2000) and 3) the Intra-Sudetic Basin (e.g., Awdankiewicz 1999a, b). The volcanic complex of the NW Polish Basin is the easternmost part of the CEBS volcanic complex and is the largest occurrence of Permian extrusive rocks in Poland. A sedimentary complex, up to $3.5 \mathrm{~km}$ thick, composed of Permian, Mesozoic, and Cainozoic sediments covers these extrusive rocks (Marek, Pajchlowa 1997; Karnkowski 1999). Karnkowski (1999) assigned the Permian volcanogenic complex of the NW Polish Basin to the Wyrzeka Formation. The thickness of the Wyrzeka volcanic sequence typically ranges from 100-200 m but may reach $1000 \mathrm{~m}$. The age of the Permian extrusive event has been estimated to be in the range 300-285 Ma (Ryka 1981; Lippolt et al. 1982; Jackowicz 1995). 
In addition, the extrusion age is constrained by paleontological data from adjacent sedimentary sequences (e.g., Kłapciński, Karwowski 1978). The volcanic activity lasted for some $15 \mathrm{Ma}$ (Ryka 1981).

For the present study, the metavolcanic rocks were sampled from drill cores obtained during exploration drilling at boreholes Namyślin 1, Witnica 1, and Dzieduszyce 1 (drilled by Geonafta, Zielona Góra) located in the Gorzów Wielkopolski Block within the NW Polish Basin (Fig. 1). All of the samples are from the upper part of the Permian volcanic layer (Dubińska et al. 2004a). Seismic data indicates that the Permian extrusive rocks overlie Lower Carboniferous clastic sediments (Fig. 3 and Dyjaczyński, Dąbrowska-Żurawik - unpublished data). These are in turn covered by a Zechstein evaporitic complex reaching ca $920 \mathrm{~m}$ in thickness and by Mesozoic and Cainozoic clastic and carbonate rocks (Dyjaczyński, pers. comm.). Faults in the Carboniferous rocks (Fig. 3,

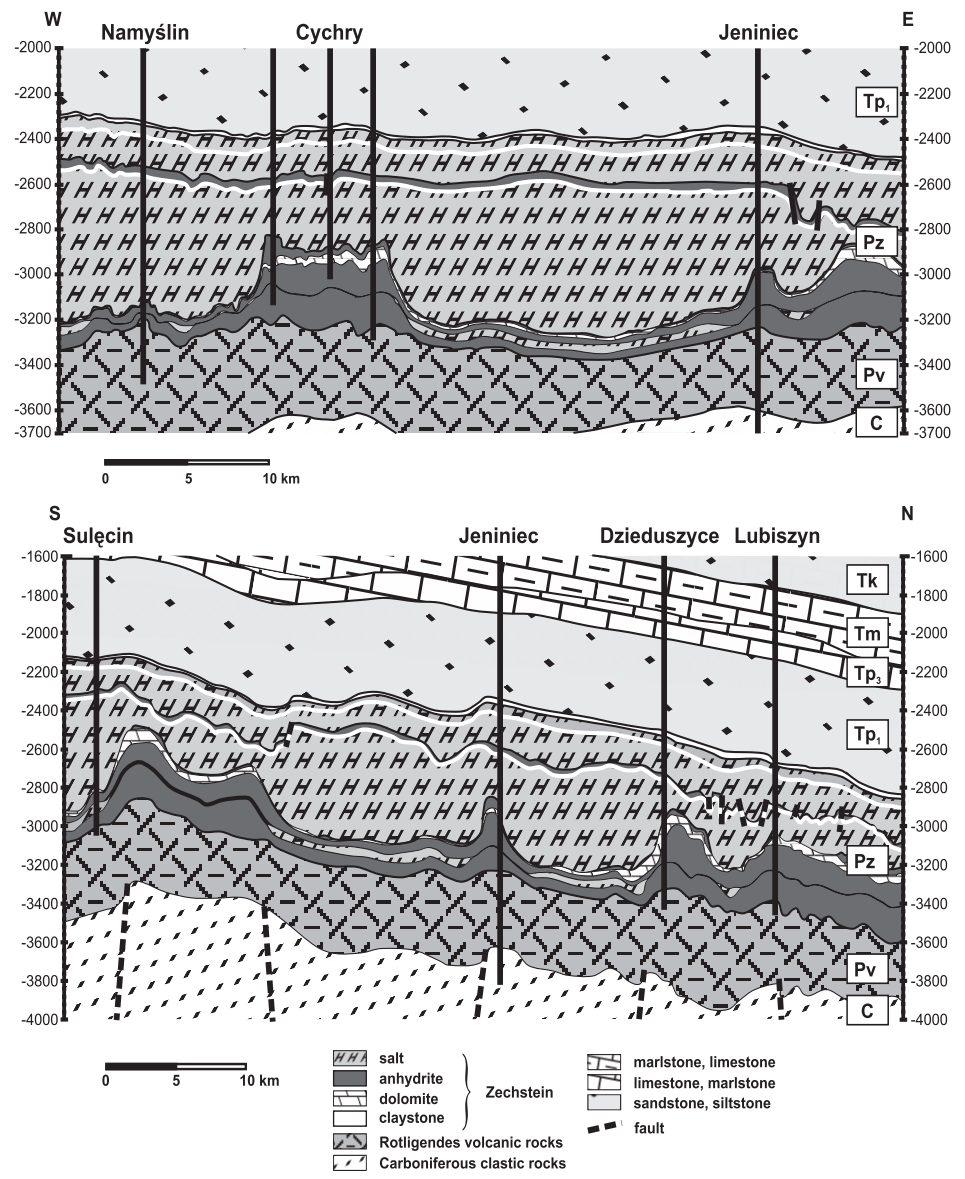

Fig. 3. Geologically interpreted seismic cross-sections from studied area (marked in Fig. 1; courtesy of Kazimierz Dyjaczyński and Elżbieta Dąbrowska-Żurawik).

Abbreviations: $\mathrm{C}-$ Carboniferous, $\mathrm{Pv}$ - Permian volcanic rocks, Pz - Permian (Zechstein),

$\mathrm{Tp}_{1}-$ Triassic (Lower Buntersandstein), $\mathrm{Tp}_{3}-$ Triassic (Upper Buntersandstein),

Tm - Triassic (Muschelkalk), Tk - Triassic (Keuper) 
NS profile) connect with distortions in the upper boundary of the Permian extrusive layer, with anhydrite pillows in the Zechstein complex and with minor bending of Triassic layers. This indicates Mesozoic tectonic activity, which was partly attenuated by the evaporite complex in a manner similar to the diapir development mechanism described by Krzywiec (2004).

\section{Pre-Permian basement}

The pre-Permian basement rocks in the NW part of the Polish Basin are poorly documented. The Lower Carboniferous rock complex, assigned to the Wielkopolska Externides, is interpreted to be a molasse-type series developed in the foreland of the Variscan Thrust Belt (e.g., Wierzchowska-Kicułowa 1984; Gregosiewicz 1986, 1990; Maliszewska 1997; Krzemiński 2002).

The pre-Carboniferous rocks are only tentatively identified as such. They comprise phyllites and quartzite schists identified in the Wolsztyn High boreholes (SW Poland). These rocks are considered to be Devonian on the basis of poorly preserved conodonts (Wierzchowska-Kicułowa 1984; Haydukiewicz et al. 1999). They suffered an Early

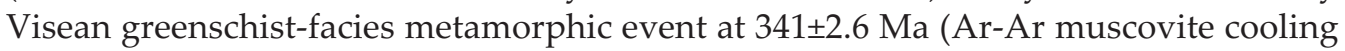
age, Żelaźniewicz et al. 2003). The thickness of the pre-Permian Palaeozoic rock complex in the Gorzów Wielkopolski area can be estimated at ca $5.2 \mathrm{~km}$ on the basis of deep seismic profiles (Janik et al. 2002).

\section{Post-Permian metamorphic and hydrothermal processes}

The Permo-Carboniferous volcanic rocks of the North German Basin and of the Polish Basin are usually altered. Secondary mineral assemblages reported to-date include corrensite, chlorite, celadonite, fine-grained micaceous phases (frequently based on optical identification only), carbonates (calcite, dolomite, siderite), $\mathrm{SiO}_{2}$-group phases (quartz, chalcedony, opal), albite, adularia, barite, pumpellyite, laumontite, actinolite, titanite and a variety of opaque minerals. Huebscher (1995), Marx et al. (1995), Brecht, Breitkreuz (1997), Brecht, Wolfgramm (1998) and Brecht 1999 have described the secondary alterations in the North German Basin. Siemaszko $(1978,1981)$, Ryka (1981), Speczik, Rydzewski (1983), Kłapciński et al. (1988), Jackowicz (1994), Dubińska et al. (1998) Sadowski, Madej (2001) and Dubińska et al. (2004a) have done likewise for the rocks of the Polish Basin.

The alteration of the Permian volcanic rocks had been ascribed to post-volcanic hydrothermal activity (e.g., Siemaszko 1978, 1981; Ryka 1981; Speczik, Rydzewski 1983). However, several studies supported by radiometric age determinations suggest that the metamorphism is mostly of Mesozoic age (Fig. 2). Metamorphic activity likely began in the Late Triassic (Brecht 1999; Michalik et al. 2003; Michalik et al. 2004) and continued until Late Jurassic times (Brecht 1999; Goll et al. 2003; E. Siemaszko, fide Dubińska et al. 2004a).

Radiometric age studies on the crystallization of pore-filling illite in the Carboniferous and Permian (Kupferschifer and Rotliegend) clastic rocks give an age spectrum 
ranging from the Late Triassic up to the Late Cretaceous (cf. Fig. 2). Górniak et al. (2004) and Protas (2004) investigated authigenic illites separated from Early Carboniferous black shales and tuffs of the Koszalin-Chojnice area. They found two age populations: 1) Late Carboniferous - Early Permian and 2) Late Triassic - Early Jurassic. Protas (2004) ascribed the unexpected Mesozoic illite ages to increased hydrothermal activity related to Alpine orogenic activity. Similarly, Kozłowska and Poprawa (2004) found, in Carboniferous sandstones, fibrous illite which they characterised as diagenetic and which crystallized in Late Triassic and Middle Jurassic times. According to their interpretation, the fibrous illite growth was caused by tectonically driven hydrothermal activity.

Numerous K-Ar geochronological studies on the Weissliegend sandstone from the SW part of Fore Sudetic Monocline, and on the ore-bearing Kupferschiefer Formation, document intense authigenic illite crystallization from the Late Triassic to the Late Jurassic and during the Late Cretaceous (Bechtel et al. 1999; Oszczepalski 1999; Michalik 2001). These events were probably related to the hydrothermal activity that was also responsible for copper ore formation (Bechtel et al. 1999; Oszczepalski 1999; Blundell et al. 2003). K-Ar ages for diagenetic illite from Rotliegend sandstones in the central part of the Polish Basin also record an unusual thermal event between Late Jurassic and Late Cretaceous times (Maliszewska 1997). These cited ages are similar to diagenetic 200-180 Ma ages obtained for authigenic illites separated from Rotliegend sandstones in north Germany (Zwingmann et al. 1999; Liewig, Clauer 2000) and in other parts of the CEBS (Michalik 2001 and references therein). In another part of the North German Basin, Kus et al. (2005) described a process of hydrocarbon generation genetically related to Early Jurassic rifting.

Several episodes of Mesozoic hydrothermal activity have been recorded close to the southern border of the North German Basin, i.e., in the Harz Mts (Boness et al. 1990; Schneider et al. 2003; Schmidt-Mumm, Wolfgramm 2004 and references therein). However, the most significant Mesozoic hydrothermal event was that responsible for the formation of a carbonate-hosted $\mathrm{Zn}-\mathrm{Pb}$ sulphide ore deposit in the Olkusz area and for which an age of $c a 135$ Ma has been determined (Heijlin et al. 2003).

\section{METHODS}

Minerals were identified using transmitted-light polarising microscopy and X-ray powder diffraction analysis (DRON 2.0 and INEL CPS-120 diffractometers, CoK $\alpha$ and $\mathrm{CoK} \alpha_{1}$ radiation, respectively). Cathodoluminescence studies were performed on a Carl-Zeiss-Jena Jenapol microscope equipped with Cold Cathodoluminescence $8200 \mathrm{Mk} 3$ (Cambridge Image Technology Ltd., UK: $20 \mathrm{kV}$ and $0.4 \mathrm{nA}$ ). UV images were recorded on a Carl-Zeiss Axiolab microscope in the Institute of Parasitology, Polish Academy of Sciences.

Mineral compositions were determined using a JEOL-JXA-840A electron microprobe equipped with a NORAN Voyager EDS system $(15 \mathrm{kV}$ and $35 \mathrm{nA}, \mathrm{ZAF}$ correction procedure) at the Institute of Geological Sciences PAS in Warsaw and using a CAMECA 
SX 100 microprobe (WDS system, $20 \mathrm{kV}$ and $15 \mathrm{nA}$, PAP correction procedure) at the Electron Microprobe Laboratory, Faculty of Geology (Warsaw University). Synthetic silicate glasses and natural minerals were used as analytical standards. BSE and X-ray emission images were recorded using the CAMECA SX 100 electron microprobe. Corrensite layer charge (cation exchange capacity) was determined in situ using a barium staining technique modified after Schiffmann and Southard (1996).

Primary and secondary fluid inclusions $(2-13 \mu \mathrm{m})$ in minerals from amygdales and veinlets were studied in double-sided polished sections $(0.2-0.5 \mathrm{~mm}$ thick) using the techniques described in detail by Dubińska et al. (2004a, b). Estimated errors for the p-T findings are as follows: crystallization temperature $\pm 1^{\circ} \mathrm{C}$, crystallization pressure $\pm 2 \mathrm{MPa}$, density of the aqueous fluid $\pm 0.01 \mathrm{~g} \cdot \mathrm{cm}^{-3}$ and density of $\mathrm{CH}_{4}$ and $\mathrm{CO}_{2}$ phases $\pm 0.02 \mathrm{~g} \cdot \mathrm{cm}^{-3}$.

Four coarse-grained whole-rock fractions $(\varphi>0.1 \mathrm{~mm})$ and one sample of vein filling were chosen for K-Ar age determinations. The fractions were ultrasonically treated to remove corrensite and other mineral species that weakly absorb potassium. In addition, the mineral composition of the residua was verified by X-ray powder diffractometry.

Samples for potassium content determination and for argon isotope analysis were weighted in air at the same time. Potassium contents were determined by flame photometry, with relative precision better than $2 \%$, after sample dissolution in a mixture of hydrofluoric- and perchloric acids. Argon isotope analyses were carried out on a mass spectrometer (MS-20) at the Institute of Geological Sciences PAS, Cracow Division. Argon was extracted from the samples by fusion in a resistance heater. A well-calibrated ${ }^{38} \mathrm{Ar}$ spike was added. The extracted argon was cleaned using two cold-finger traps and a heated titanium absorber on the vacuum line. Cyclic measurements of the international GLO glauconite standard were made. The errors include all uncertainties in the measurement of the isotope ratios and the $\mathrm{K}$ contents. All are quoted in the text as $\pm 2 \sigma$. The decay constants and isotopic abundances used for age calculation are those recommended by Steiger and Jäger (1977).

\section{MINERALOGICAL AND PETROLOGICAL CHARACTERISTICS}

As noted above, the metavolcanic rocks were sampled from drill cores recovered from the Dzieduszyce 1, Namyślin 1, and Witnica 1 boreholes in the Gorzów Wielkopolski region (Fig. 1). The samples represent the upper zone of the Rotliegend volcanic sequence (3000-3300 m below ground level). The rocks are highly variable and macroscopically inhomogeneous and range from dark-grey almost homogeneous varieties to spotted greyish, grey-greenish, reddish and blackish rocks. Some are amygdaloidal, others are not. Veins of different thickness and composition commonly cut these rocks. The proportion of veins can be substantial. Extreme examples are essentially breccias composed of metavolcanic rock clasts cemented by veinlets of quartz or calcite. 

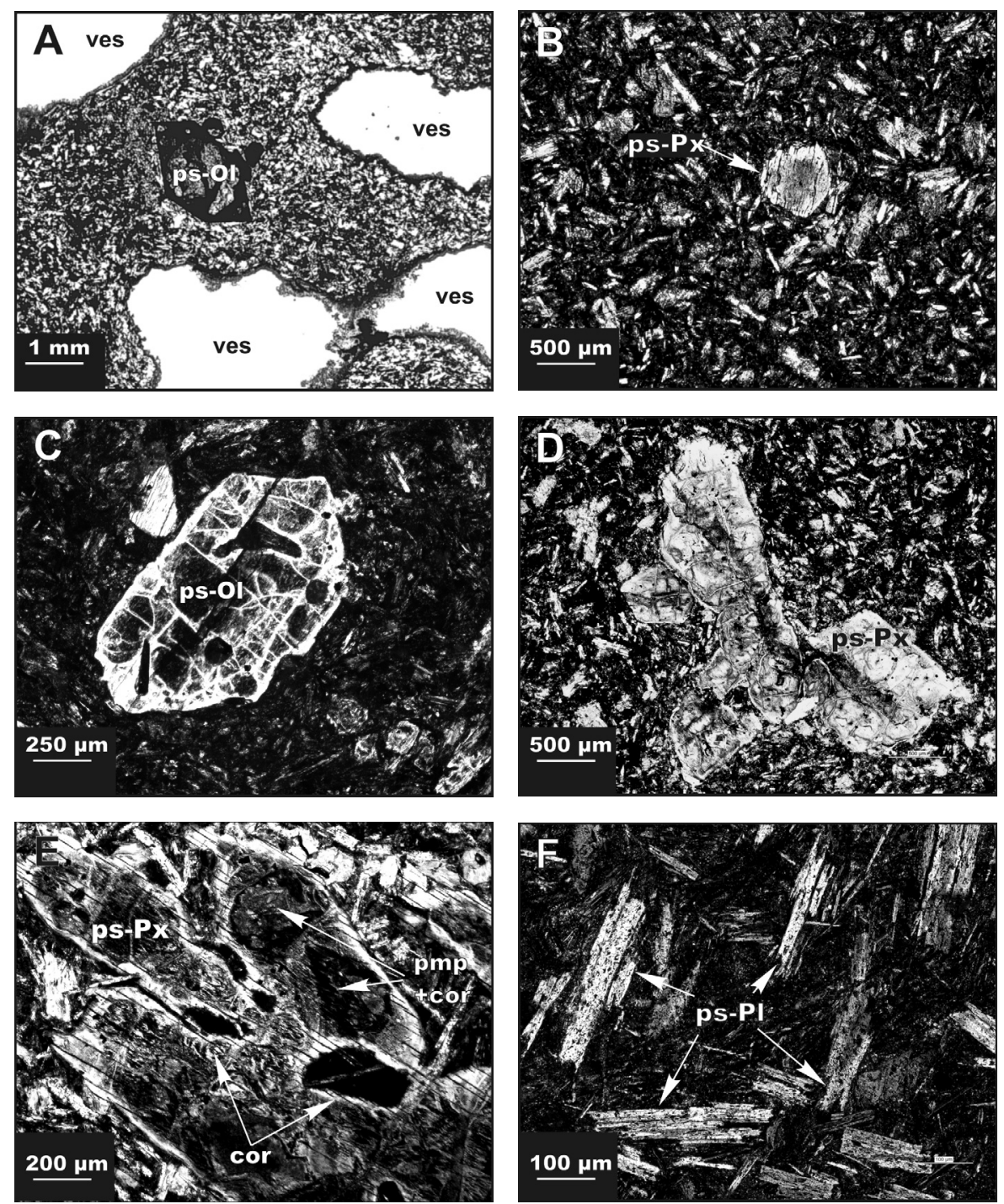

Fig. 4. Microphotographs of volcanic rocks showing primary textures and pseudomorphs after primary minerals. A. Pseudomorph (after olivine) and vesicles in altered matrix of pseudomorphed plagioclase and pyroxene; groundmass pilotaxic texture clearly evident (Namyślin $3221.0 \mathrm{~m}$ ); one polar.

B. Pseudomorph after pyroxene within altered groundmass (Namyślin 3221.0); crossed polars.

C. Pseudomorph after olivine (Namyślin 3220.0); crossed polars. D. Glomeroporphyritic cluster of pseudomorphs after pyroxene (Namyślin 3221.0); one polar. E. Fragment of pseudomorph after pyroxene

with tabular 'corrosion' embayments; rim of pseudomorph is composed of corrensite, inner part is a pumpellyite-corrensite intergrowth (Namyślin 3226.0); one polar. F. Pseudomorphs composed of albite, pumpellyite, and K-feldspar after plagioclase (Namyślin 3225.0); crossed polars.

Abbreviations: ab - albite, anh - anhydrite, bit - bitumen, cc - calcite, ch - chalcedony,

ctl - chlorite, CM - chlorite-like minerals, cor - corrensite, Kfs - K-feldspar, qtz - quartz, pmp - pumpellyite, ps-Ol - pseudomorph after olivine, ps-Pl - pseudomorph after plagioclase, ps-Px - pseudomorph after pyroxene, ttn - titanite, ves - vesicle 
Magmatic texture and primary mineralogy

Microscopically, the primary magmatic texture is well preserved (Fig. 4). The rocks contain numerous pseudomorphs after coarse $(<5 \mathrm{~mm})$ olivine- and pyroxene phenocrysts. Some pseudomorphs are grouped into glomeroporphyritic clusters (Fig. 4D). Groundmass pilotaxitic texture is well preserved even though the groundmass minerals, with pseudomorphs after plagioclase and pyroxene microphenocrysts prominent, are strongly altered. The rocks contain abundant spherical or ellipsoidal $(2-20 \mathrm{~mm})$ vesicles filled with secondary mineral phases (Fig. 4A).

Spinel and clinopyroxene are the only primary minerals that survived alteration (Table 1). The spinel is preserved as inclusions in pseudomorphs after mafic minerals. Extremely rare relicts of clinopyroxene form minute inclusions in pseudomorphs after pyroxene phenocrysts and after groundmass microphenocrysts (Dubińska et al. 2004a). Several fine grains of K-feldspar were noted in the altered groundmass of the Dzieduszyce 1 sample. However, it proved difficult to establish whether they belong to the primary or secondary mineral assemblages.

\section{Alteration style and secondary minerals}

All of the rocks are composed mainly of secondary minerals. The metamorphic assemblage comprises corrensite, chlorite, pumpellyite, albite, K-feldspar, laumontite and quartz (Fig. 5) together with minor titanite, anhydrite, prehnite, calcite and asphaltite (bitumen). Representative secondary-mineral compositions are shown in Table 1.

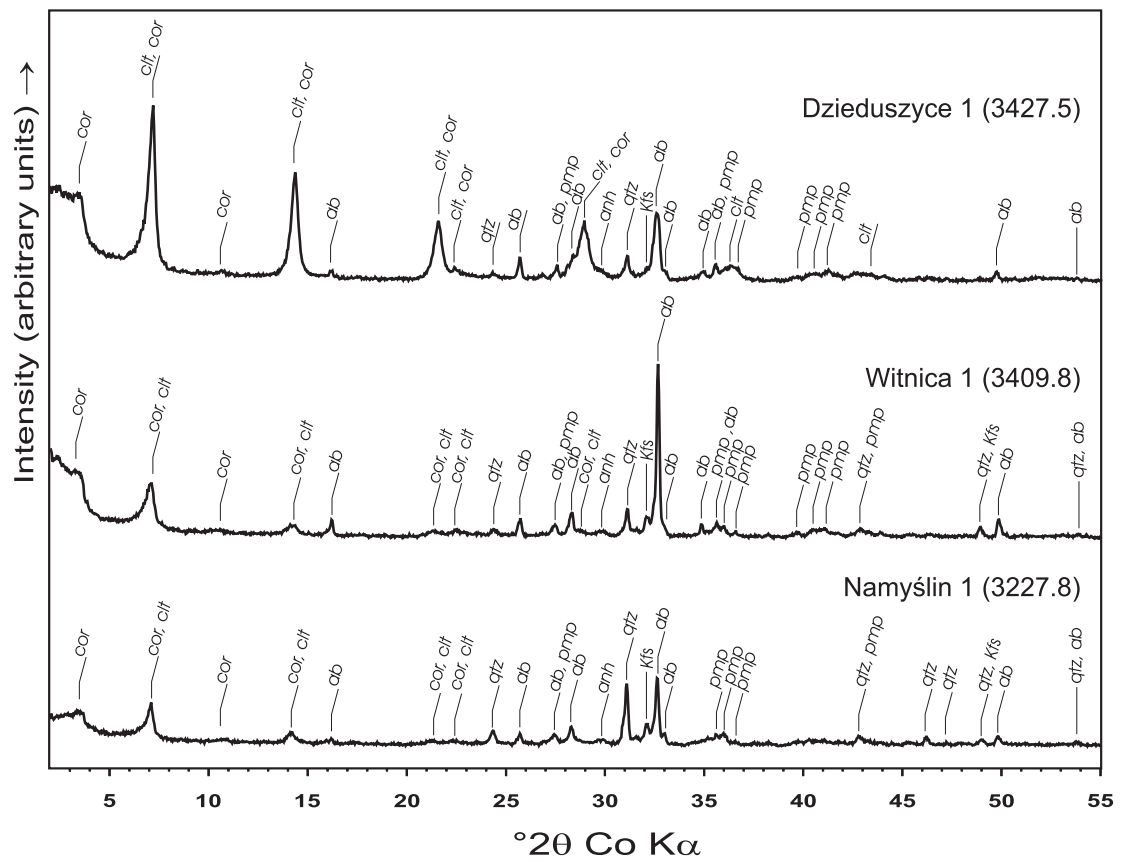

Fig. 5. X-ray diffraction patterns of whole-rock samples; see the caption of Figure 4 for abbreviations 
Mafic phenocrysts are completely replaced by a mixture of corrensite, chlorite, and Al-rich pumpellyite (Bylina et al. 2000). Corrensite-pumpellyite aggregates are typically located in the centres of pseudomorphs whereas pseudomorph rims are composed of corrensite-chlorite intergrowths (Fig. 4E). Pumpellyite often forms zig-zag intergrowths with corrensite; this can be a result of volume increase in a limited or closed space (A. Barronet, fide Dubińska et al. 2004a). Aggregates of titanite and scarce celadonitic mica also occur in pseudomorphs after mafic minerals (Fig. 6 - Ti and Ca; Dubińska et al. 1998; Bylina et al. 2000).

The majority of groundmass minerals are secondary in origin although the pristine groundmass texture is preserved. Microphenocrysts of plagioclase, the main compo-

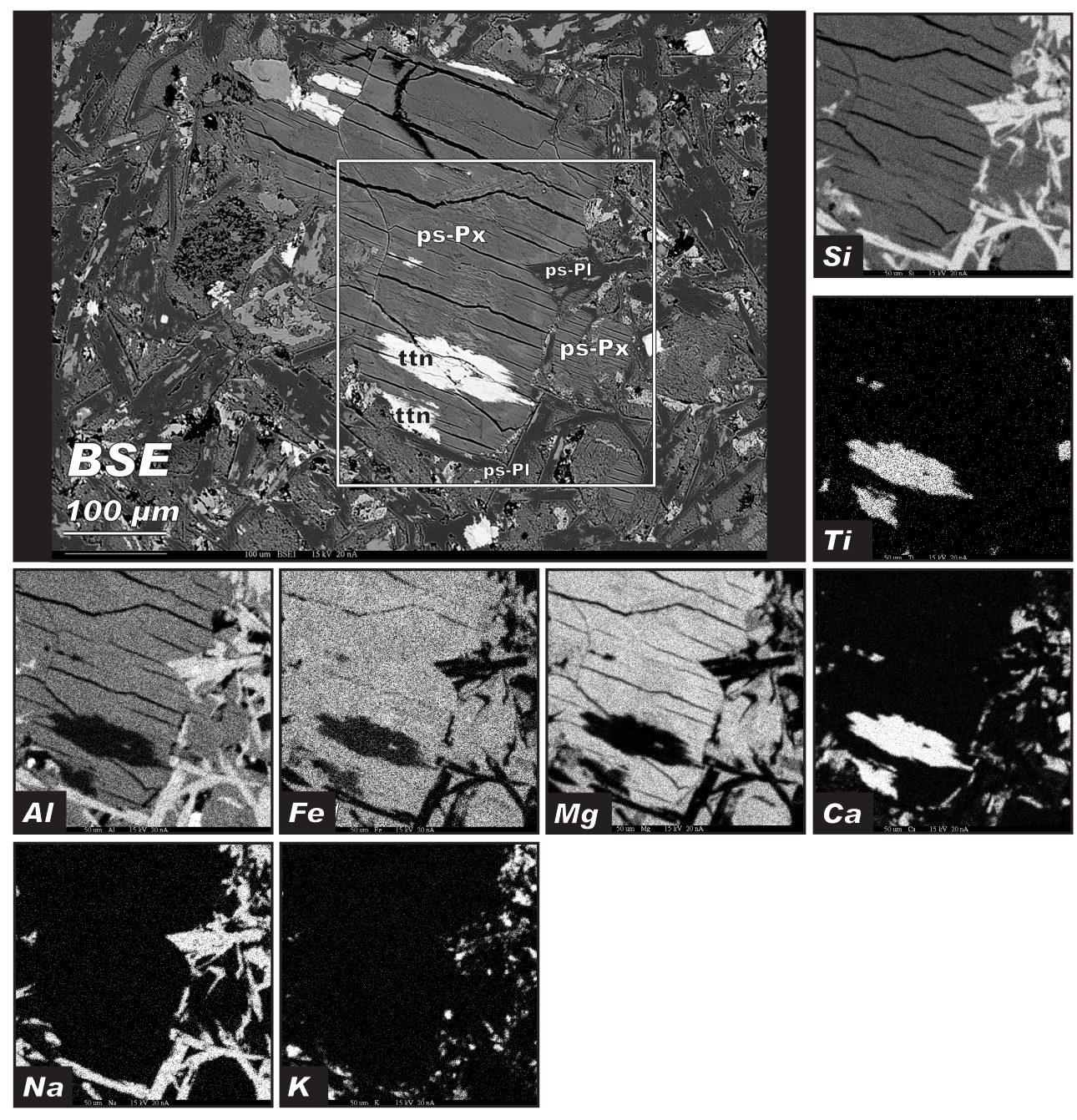

Fig. 6. BSE image of pseudomorph after pyroxene within an altered groundmass (Namyślin $3227.5 \mathrm{~m}$ ); X-ray emission maps show distribution of secondary minerals including corrensite $(\mathrm{Mg})$, potassium feldspar $(\mathrm{K})$, titanite $(\mathrm{Ti})$, titanite and pumpellyite $(\mathrm{Ca})$ and albite $(\mathrm{Na})$ 
nent of groundmass, are completely replaced by a mixture of albite, pumpellyite and K-feldspar (Fig. 6). Albite occurs as oriented aggregates forming pseudomorphs after Ca-rich plagioclase whereas K-feldspar and Fe-rich pumpellyite are scattered within (Fig. $6-\mathrm{K}$ and $\mathrm{Na}$ ). Replacements after glass patches are commonly composed of
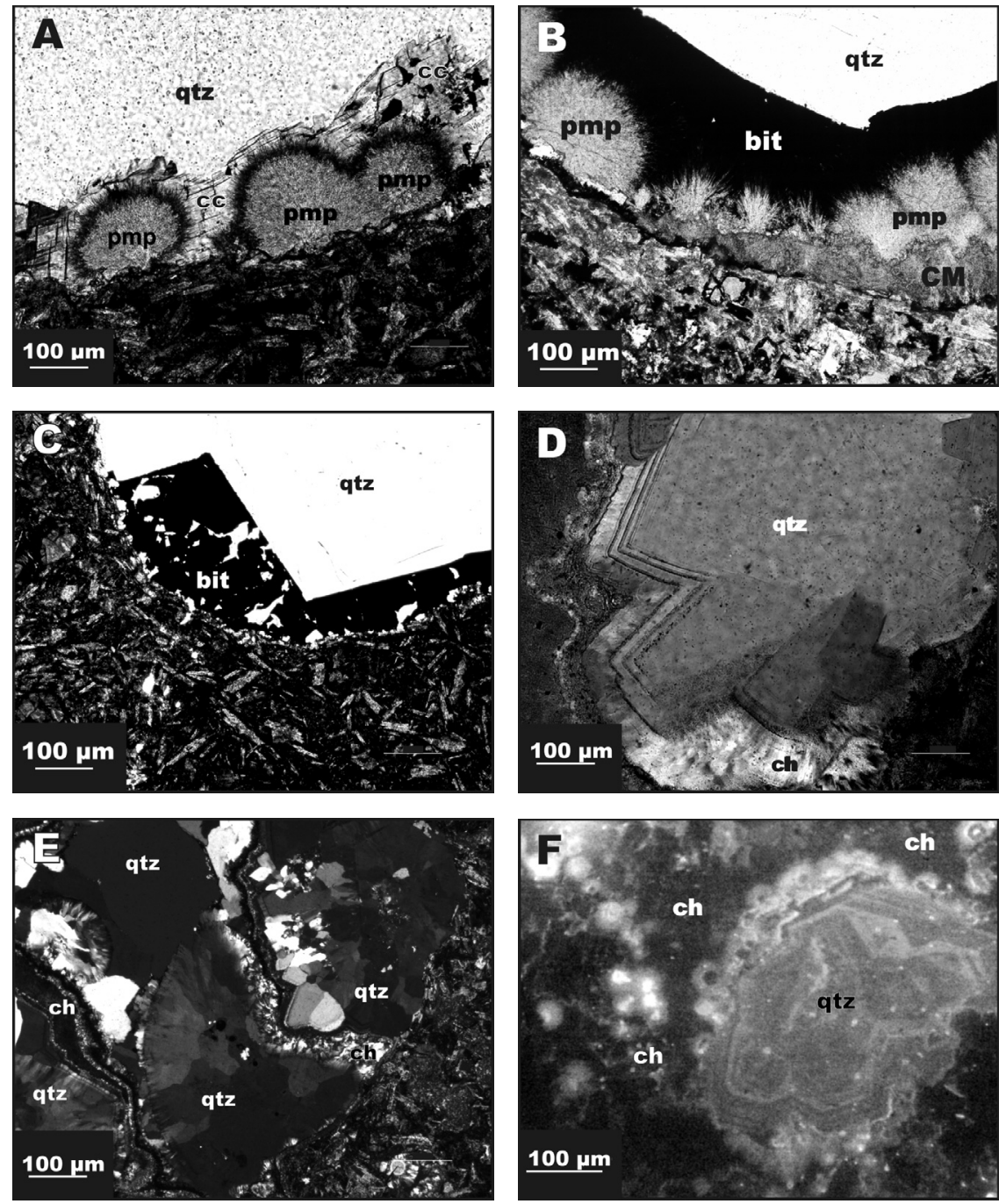

Fig. 7. Microphotographs of amygdale filling.

A. Fan-like aggregates of pumpellyite coated with bitumen and covered by calcite and quartz (Namyślin $3227.5 \mathrm{~m}$ ); one polar. B. Fan-like aggregates of pumpellyite growing on chlorite-like minerals and covered by solid bitumen and quartz (Namyślin 3227.5); one polar. C. Solid bitumen filling a gap between amygdale rim and quartz (Namyślin 3225.5); one polar. D. Quartz crystal with distinct zoning and chalcedony overgrowth (Namyślin 3227.0); crossed polars. E. Amygdale filled with several quartz crystals and chalcedony; some quartz crystals exhibit mosaic structure; crossed polars (Namyślin 3227.0).

F. Quartz crystal in chalcedony matrix (Namyślin 3358.5); cathodoluminescence. See the caption of Figure 4 for abbreviations 
pumpellyite and corrensite ( \pm chlorite). The groundmass pumpellyite forms intergrowths with laumontite, quartz, and fine-grained titanite. Titanite also occurs as lamellar aggregates surrounding pseudomorphs after plagioclase.

Amygdales and veins contain multiple generations of anhydrite, corrensite $( \pm$ chlorite), pumpellyite, laumontite and quartz with minor asphaltite (bitumen), calcite, and albite. Irrespective of the phases present, amygdale cores are coarse-grained aggregates whereas rims are composed of fine-grained phases (Fig. 7).

The variations in mineral composition, together with the zonation of phases in the amygdales and veins, strongly suggest the involvement of several hydrothermal events in the alteration history of the rocks. The spatial pattern, supported by the variability in chemical composition, allows the sequence of the mineral-forming events to be established (Fig. 8).

albite
layer silicates
pumpellyite
titanite
anhydrite
laumontite
quartz
prehnite
bitumen
calcite
chalcedony

Fig. 8. Paragenesis of secondary minerals in the metavolcanic rocks based on petrological and mineralogical observations and fluid inclusion measurements

\section{Layer silicates}

In the metavolcanic rocks, layer silicates are represented by corrensite, chlorite and celadonitic mica (Table 1). Corrensite and chlorite are the major alteration products. Celadonitic mica is found as an accessory mineral in veins and as a minor component in corrensite-chlorite intergrowths in rock from Dzieduszyce 1 only.

Corrensite occurs as a quasi-regular chlorite-smectite interstratified mineral (Bylina et al. 2000). It forms submicroscopic intergrowths with chlorite and pumpellyite in all pseudomorphs after mafic minerals as well as in the altered groundmass. Corrensite from pseudomorph rims is typically richer in $\mathrm{Mg}$ compared to that in the cores, which is relatively Fe-rich. The observed variation in element content suggests $\mathrm{Al}(\mathrm{IV})-\mathrm{Fe}^{3+}(\mathrm{VI})$ 
and $\mathrm{Mg}(\mathrm{VI})-\mathrm{Fe}^{2+}(\mathrm{VI})$ substitutions. The layer charge of the corrensite is nearly constant at $0.36 \pm 0.04$ charge per formula unit (see Bylina et al. 2000 for details).

\section{Albite and K-feldspar}

Albite is one of main phases that formed during alteration. It commonly occurs as pseudomorphs after plagioclase (Fig. 4F, Fig. $6-\mathrm{Na}$ ) and occasionally as inclusions in quartz grains inside amygdales. Analytical data indicate that the chemical composition of the albite is homogeneous and close to the stoichiometric composition (Table 1). The presence of $\mathrm{K}, \mathrm{Mg}$, and $\mathrm{Ca}$ can be attributed to submicroscopic intergrowths of pumpellyite and K-feldspar.

In the Namyślin 1 and Witnica 1 rocks, K-feldspar occurs as minute inclusions (25-50 $\mu \mathrm{m})$ in pseudomorphs after plagioclase. It seems to be a product of metamorphic recrystallization. K-feldspar also occurs as fine individual grains in the groundmass (Fig. $6-\mathrm{K}$ ). However, the latter K-feldspar cannot be unequivocally assigned to the secondary mineral assemblage.

\section{Pumpellyite}

Pumpellyite is the main secondary mineral in the rocks from Namyślin 1 and Witnica 1 (for details, see Dubińska et al. 1998). It commonly forms spherulites in veins and amygdales (Fig. 7A and B), zig-zag aggregates (together with corrensite) in pseudomorphs after pyroxene phenocrysts (Fig. 4E) and inclusions in pseudomorphs after plagioclase microphenocrysts (Fig. 6 - Ca and Al). Two forms of pumpellyite can be distinguished: 1) a Fe-rich, golden-brown, fine-grained variety and 2) an Al-rich, apple-green, needle-like variety (Table 1). The relatively rare Fe-rich pumpellyite can be recognized as of an older generation whereas the Al-rich variety is younger and prevails. No unequivocal relationship between chemical composition and pumpellyite occurrence was identified.

In general, pumpellyite, albite and corrensite formed simultaneously. In amygdales, pumpellyite usually crystallized later than corrensite ( \pm chlorite). Al-rich pumpellyite is commonly seen to have replaced anhydrite. Pumpellyite spherulites in amygdales are often coated or covered with bitumen and, as a rule, pre-date quartz, calcite and laumontite (Fig. 7A, B).

\section{Quartz and chalcedony}

Quartz is a ubiquitous product of the alteration processes. It occurs as idiomorphic crystals, up to several millimetres in diameter (Fig. 7), in amygdales and veins and as minute grains in the altered groundmass. Coarse-grained idiomorphic quartz crystals show several growth zones that may be evidence of multiple hydrothermal events (Fig. 7D, F). Quartz commonly replaced anhydrite. It formed also as a late mineral replacing laumontite, calcite (Fig. 7A) and bitumen (Fig. 7B, C). Quartz-pumpellyite temporal relations are unclear. Dubińska et al. (2004a), however, suggest that quartz formed simultaneously with pumpellyite or, in some cases, later. 
Chalcedony is the last phase to have formed in amygdales. It is the main component of veinlets and also occurs cementing hydraulic breccias (Fig. 9E, F). Chalcedonic rims usually mark the end of coarse-grained quartz crystallization (Fig. 7D, E, F).
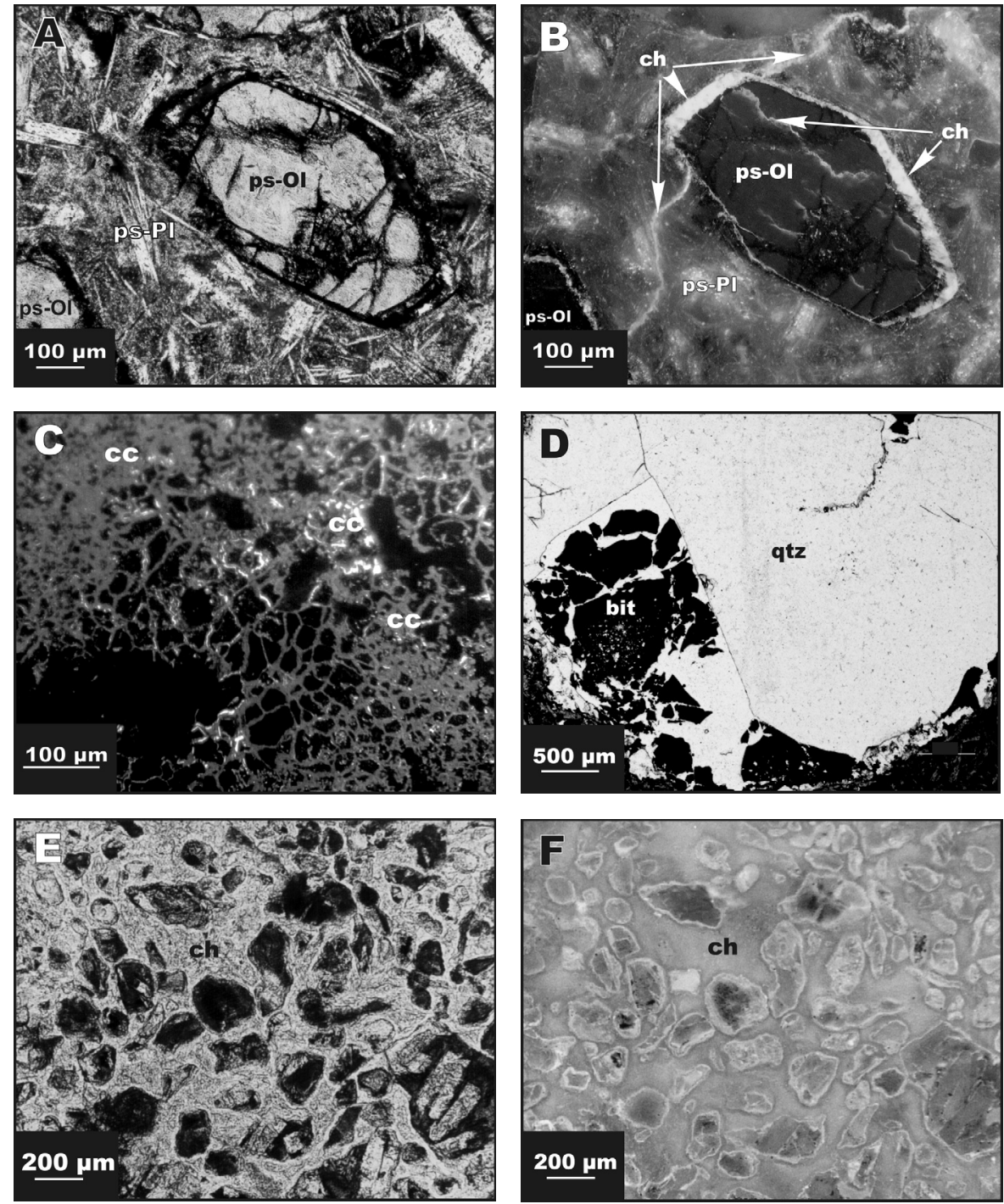

Fig. 9. Microphotographs of fracturing and brecciation.

A. Pseudomorphs after olivine within groundmass composed of pseudomorphs after plagioclase microphenocrysts (Namyślin $3224.0 \mathrm{~m}$ ); one polar. B. UV fluorescence image of the pseudomorphs

in image A; A displaced pseudomorph from its place and fine fractures filled with chalcedony.

C. Cathodoluminescence image of breccia composed of metavolcanic rock clasts cemented with calcite; (Witnica 3411.0). D. Brecciated bitumen aggregate in quartz-filled amygdale (Namyślin 3225.5); one polar.

E. Breccia composed of metavolcanic rock fragments cemented with chalcedony (Namyślin 3232.2).

F. UV fluorescence image of the breccia from image $E$; the clasts appear to be totally suspended in a matrix of chalcedony; (Namyślin 3232.2). See the caption of Figure 4 for abbreviations 
Titanite

Titanite occurs as irregular, extremely fine-grained, rounded aggregates inside pseudomorphs, in the groundmass and in some amygdales. It also forms rims surrounding pseudomorphs after plagioclase. Titanite probably developed after crystallization of albite and corrensite but appears to have crystallised at the same time as pumpellyite.

Anhydrite

Anhydrite is relatively common in veins and amygdales. However, its overall distribution in the rocks is inhomogeneous. The anhydrite-rich zones commonly border zones devoid of anhydrite. It is likely that anhydrite is the oldest phase in amygdales and veins. Anhydrite is often replaced by Al-rich pumpellyite and quartz.

Prehnite

Prehnite is an accessory secondary component in the rocks. It occurs as minute grains in mafic pseudomorphs and as inclusions in amygdale-hosted quartz grains; its occurrence is similar to that of pumpellyite. Prehnite was identified using transmitted polarized light and an electron microprobe. Its chemical composition closely matches theoretical-formula values (Table 1).

Calcite and asphaltite

Calcite occurs as a late void-filling mineral, as a coating on pumpellyite spherulites and as a cement in hydraulic breccias (Figs 7A and 9C). Laumontite is an early phase occurring, together with anhydrite, in vesicles.

Asphaltite (bitumen) occurs as a late phase filling vesicles and as veins (Figs 7B, C and 9D). Typically, bitumen forms black coatings on pumpellyite spherulites. However, fine pumpellyite needles may pierce the bitumen coatings (Dubińska et al. 2004a).

\section{Fracturing and brecciation}

Macroscopically, some of the rocks are brecciated with volcanic rock fragments cemented by veins. In addition, there is microscopic evidence of fracturing and of crushing. Pseudomorphs may be displaced from their original positions. Fractures in these pseudomorphs are mostly filled with chalcedony (Fig. 9A, B). Some rock fragments and amygdale fillings are disrupted and cemented by calcite or quartz (Fig. 9C, D). Extreme examples show fine-grained clasts of altered rock floating, as it were, in a chalcedony matrix (Fig. $9 \mathrm{E}$ and F). 


\section{GEOCHEMICAL CHARACTERISTICS}

The rocks are characterised by chemical compositions ranging from andesite-basalt to andesite (Fig. 10A). A detailed geochemical study by Dubińska et al. (2004a) showed that the parent magma was a within-plate subalkaline basalt melt but with a trace-element composition that suggests a degree of crustal contamination. This study also revealed a geochemical affinity with Permian volcanic rocks from E Brandenburg, Germany (Benek et al. 1996). Dubińska et al. (2004a) ascribed variation in REE contents to dilution of the primary-rock chemical compositions due to crystallization of new minerals during the alteration, i.e., quartz and anhydrite. Comparison of the commonly used geochemical discrimination diagrams $\mathrm{Zr} / \mathrm{TiO}_{2}$ vs. $\mathrm{Nb} / \mathrm{Y}$ and $\mathrm{SiO}_{2}$ vs. $\mathrm{Zr} / \mathrm{TiO}_{2}$ reveals $\mathrm{SiO}_{2}$ gains that can exceed $10 \mathrm{wt} \%$ (Fig. 10; see immediately below).

During low-grade metamorphism, several major elements are mobile due to the dissolution of primary minerals and glass, and the crystallization of secondary minerals. These gained or lost elements can be identified by simple comparison of inert element contents and inert element vs. suspect element ratios. Simulated gain or loss of an element causes diagonal scatter of analytical points on the relevant diagrams whereas dilution or enrichment results in horizontal scatter (Fig. 11A). Neodymium was arbitrarily selected as an inert element.

Using data from Dubińska et al. (2004a), and following the simple procedure outlined immediately above, $\mathrm{Si}, \mathrm{Al}, \mathrm{Mg}$, and $\mathrm{Ca}$ appear to have been actively gained or lost during alteration (Fig. 11A, B, E, F) and Ti and Fe passively diluted (Fig. 11C, D). The status of the remaining elements is unclear. The observed scatter in $\mathrm{K}_{2} \mathrm{O} / \mathrm{Nd}$ values can be attributed to inhomogeneous distribution of potassium feldspar, the principal K-bearing phase (Fig. 11G). Any conclusion as to whether $\mathrm{Na}$ was gained or lost remains equivocal (Fig. 11H); the scatter in values could be ascribed to inhomogeneous Na contamination.
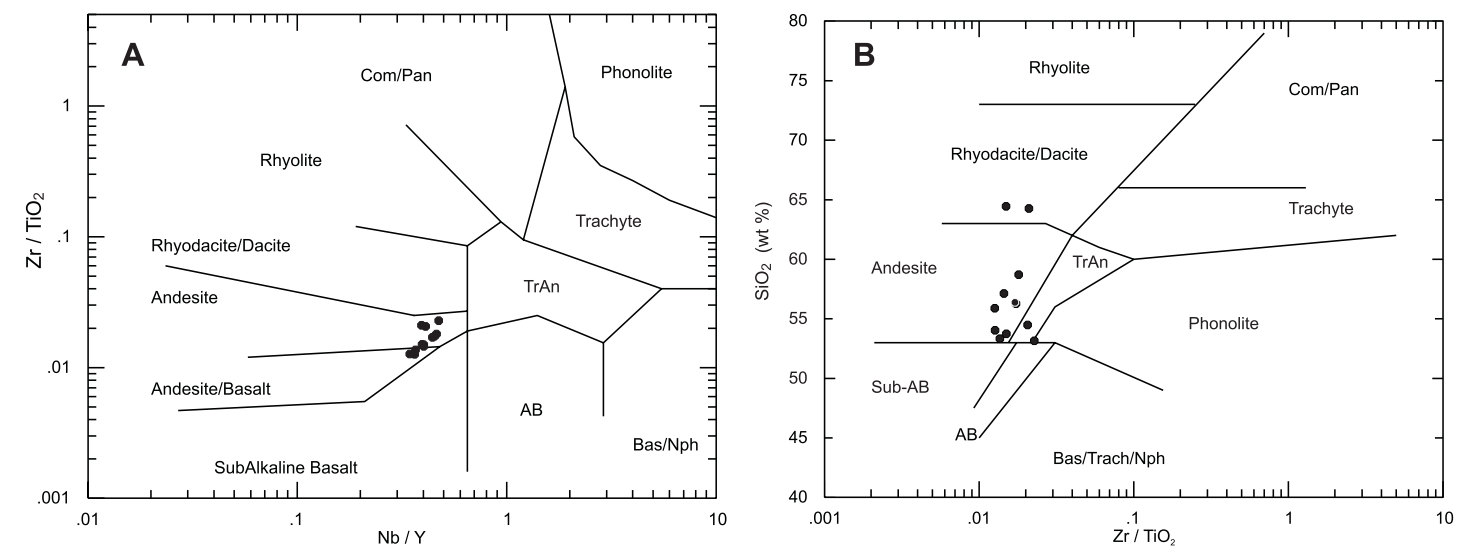

Fig. 10. A. $\mathrm{Nb} / \mathrm{Y}$ vs. $\mathrm{Zr} / \mathrm{TiO}_{2}$ discrimination diagram; $\mathrm{B}$. $\mathrm{Zr} / \mathrm{TiO}_{2} \mathrm{vs} \mathrm{SiO}_{2}$ discrimination diagram; both diagrams after Winchester and Floyd (1977); source of geochemical data - Dubińska et al. (2004a); abbreviations: $\mathrm{AB}$ - alkaline basalt, Bas - basanite, Com - comendite, TrAn - trachyandesite, Trach - trachyte, Nph - nephelinite, Pan - pantellerite, Sub-AB - sub-alkaline basalt 
The $\mathrm{SiO}_{2}$ and $\mathrm{Al}_{2} \mathrm{O}_{3}$ contents are negatively correlated $\left(\mathrm{R}^{2}=0.52\right.$, Fig. $\left.12 \mathrm{~A}\right)$. This correlation can be explained by simultaneous $\mathrm{SiO}_{2}$ addition and $\mathrm{Al}$ removal. The relationship between $\mathrm{MgO}$ and $\mathrm{SiO}_{2}$ is rather complicated (Fig. 12B). The correlation $\left(\mathrm{R}^{2}=0.05\right)$ is very weak. However, if two extreme points are excluded $\left(\mathrm{SiO}_{2}\right.$ at $c a 58 \mathrm{wt} \%$ and $\mathrm{MgO}$ at $\mathrm{ca} 4.9 \mathrm{wt} \%)$, the remaining points are positively correlated $\left(\mathrm{R}^{2}=0.61\right)$.
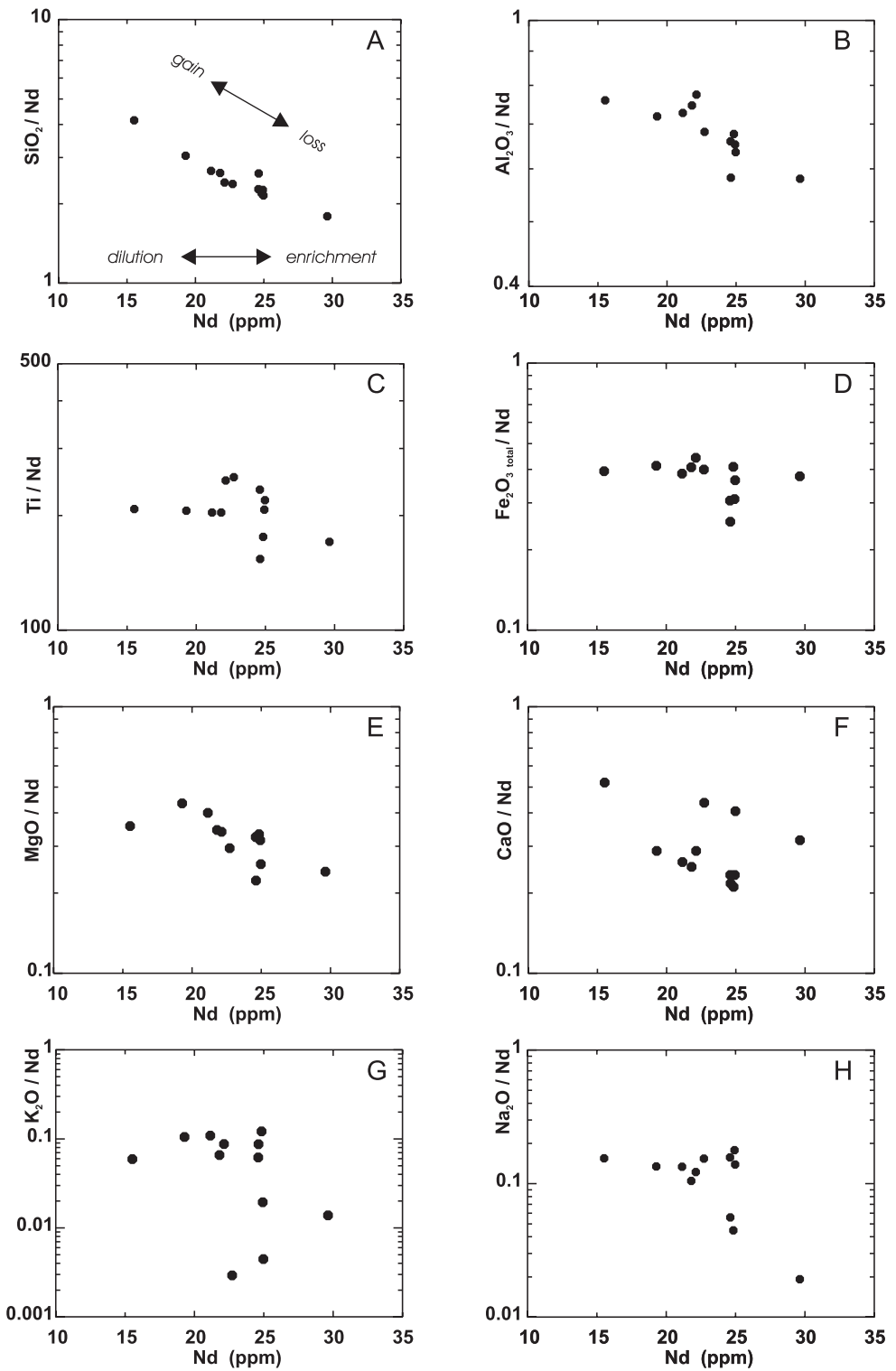

Fig. 11. Neodymium normalized diagrams.

A. $\mathrm{SiO}_{2} / \mathrm{Nd}$ vs. Nd. B. $\mathrm{Al}_{2} \mathrm{O}_{3} / \mathrm{Nd}$ vs. Nd. C. Ti/Nd vs. Nd. D. $\mathrm{Fe}_{2} \mathrm{O}_{3 \text { total }} / \mathrm{Nd}$ vs. Nd. E. $\mathrm{MgO} / \mathrm{Nd}$ vs. Nd. F. $\mathrm{CaO} / \mathrm{Nd}$ vs. Nd. G. $\mathrm{K}_{2} \mathrm{O} / \mathrm{Nd}$ vs. $\mathrm{Nd}$. $\mathrm{H}$. $\mathrm{Na}_{2} \mathrm{O} / \mathrm{Nd}$ vs. $\mathrm{Nd}$;

source of geochemical data - Dubińska et al. (2004a); see text for discussion 

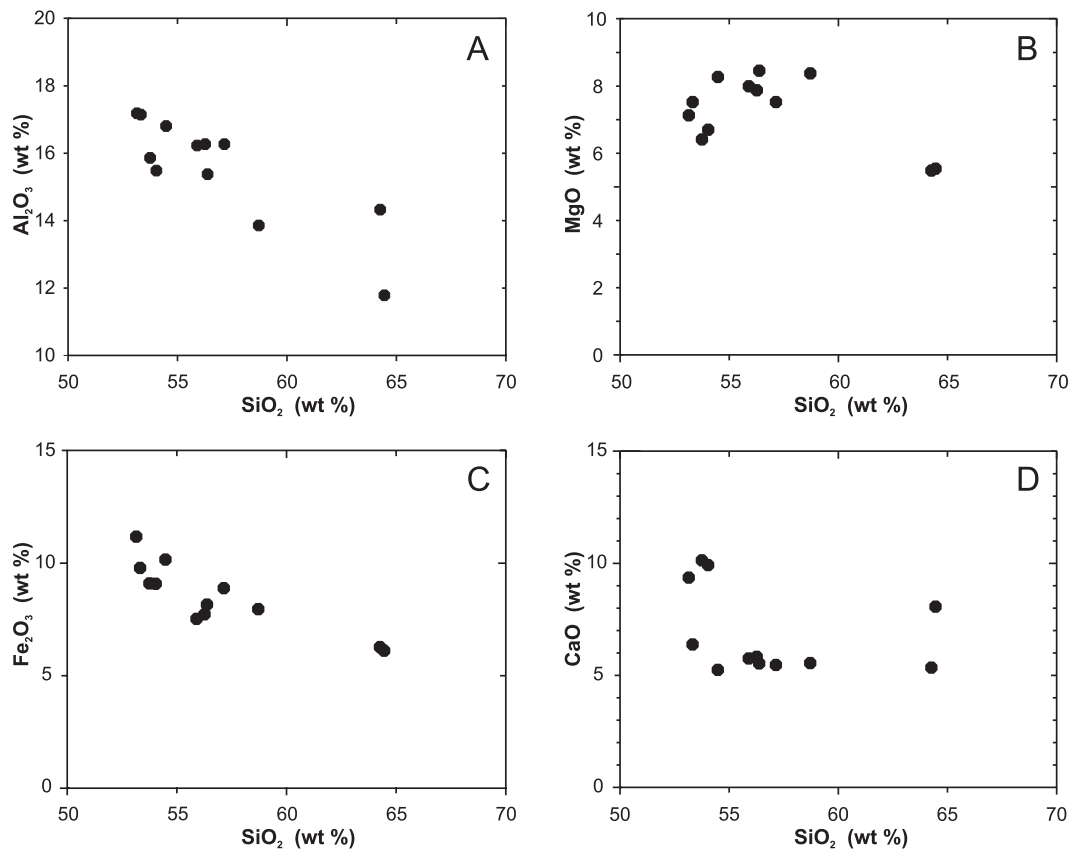

Fig. 12. Pseudo-Harker plots.

A. $\mathrm{Al}_{2} \mathrm{O}_{3}$ vs. $\mathrm{SiO}_{2}$. B. $\mathrm{MgO}$ vs. $\mathrm{SiO}_{2}$. C. $\mathrm{Fe}_{2} \mathrm{O}_{3 \text { total }}$ vs. $\mathrm{SiO}_{2}$. D. $\mathrm{CaO}$ vs. $\mathrm{SiO}_{2}$; source of geochemical data - Dubińska et al. (2004a)

This suggests concurrent delivery of $\mathrm{Si}$ and $\mathrm{Mg}$ during the alteration of the rocks. Strong correlation between Fe and silica content $\left(R^{2}=0.82\right)$ confirms dilution and inert Fe behaviour during the alteration (Fig. 12C). Variation in Ca content compared with silica content is rather ambiguous (Fig. 12D). Two populations of points, and the nearly constant $\mathrm{Ca}$ content that is independent of that of silica, suggest difference in the primary composition of the rocks and also coupled $\mathrm{Ca}$ and Si gains during the metamorphism.

\section{FLUID INCLUSION STUDY}

Primary and secondary fluid inclusions were found in quartz, anhydrite, albite and in the calcite present in veinlets and amygdales. Aqueous fluid inclusions in quartz are irregular and/or rounded in shape and range in size from 2-13 $\mu \mathrm{m}$. Only in rare instances are they associated with co-genetic gaseous inclusions (Fig. 13A, B). Gaseous inclusions, similar in size to the aqueous inclusions, are always elongated. Quartz cores may host inclusions with liquid hydrocarbons and methane (Table 2, no. 31). Anhydrite and calcite contain aqueous two-phase inclusions only. These latter inclusions often exhibit irregular or 'negative crystal' forms (Fig. 13C).

Microthermometric data obtained from inclusions hosted in quartz are internally consistent (Table 2). However, the results for inclusions hosted in calcite and anhydrite 


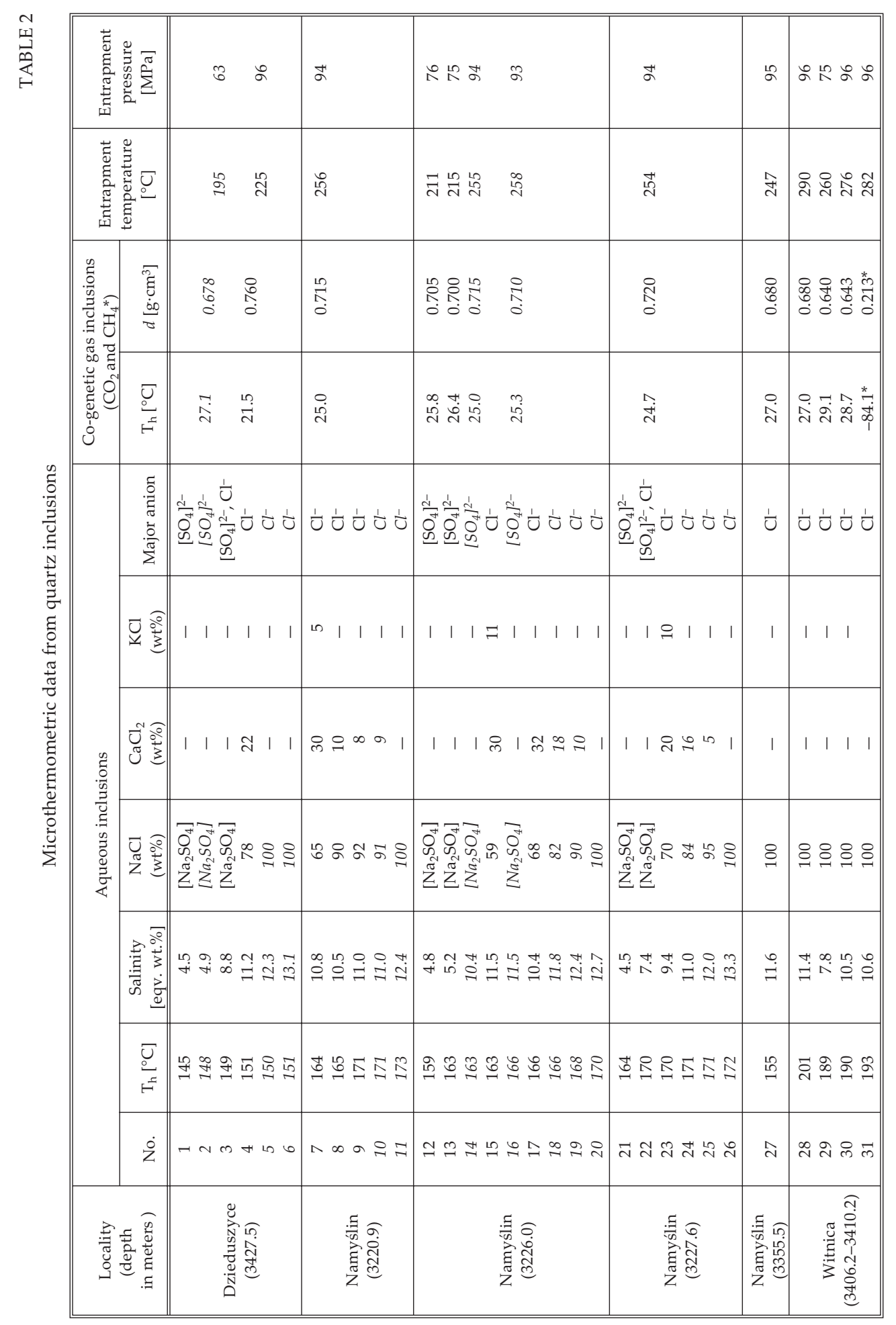



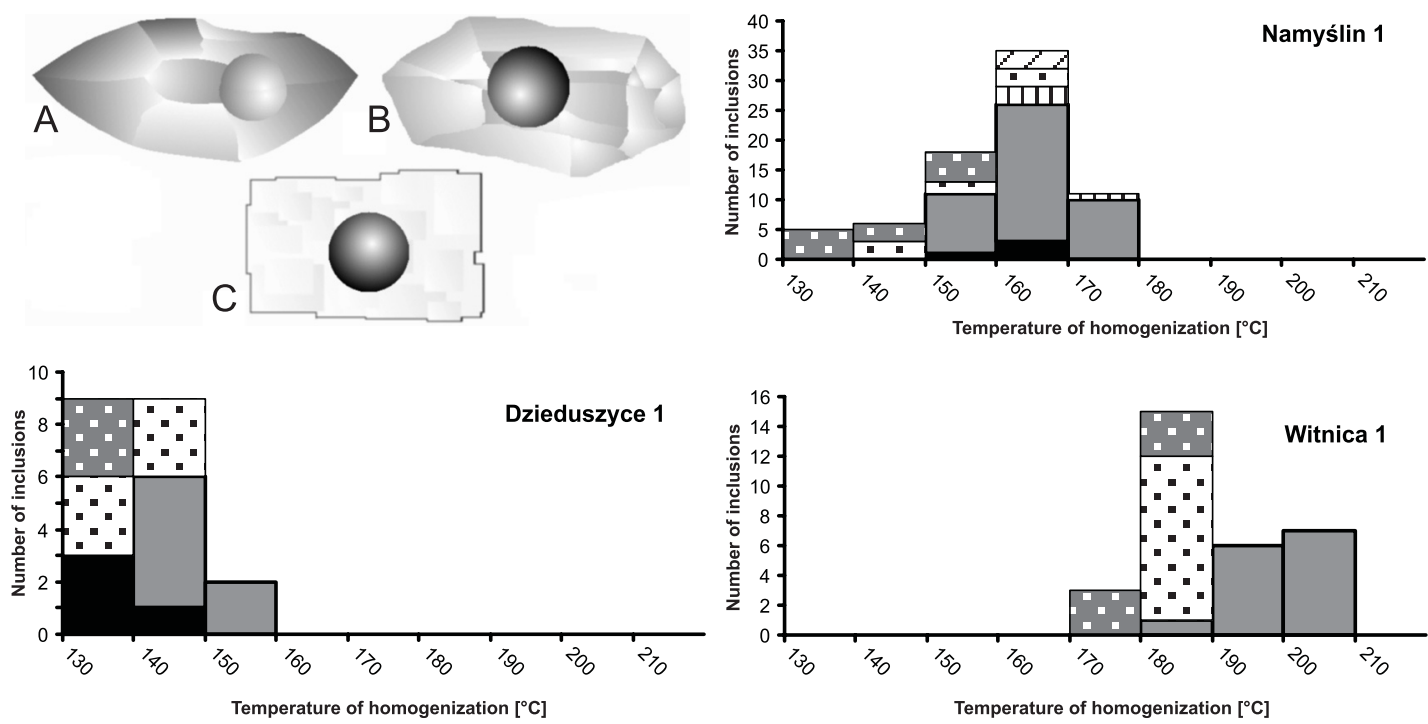

quartz from groundmass

ШII albite $\because .$. anhydrite

calcite chalcedony

Fig. 13. Fluid inclusions and homogenization-temperature diagrams. A. Drawing of two-phase $\mathrm{CO}_{2}$ inclusion trapped in quartz crystal. B. Aqueous inclusion co-genetic with $\mathrm{CO}_{2}$ inclusion shown on image A.; both inclusions are described in Table 2 (no. 27).

C. Aqueous inclusion trapped in anhydrite from Namyślin $1(3226.0 \mathrm{~m}) \mathrm{T}_{\mathrm{h}}=153^{\circ} \mathrm{C}$

are less reliable because of the perfect cleavage of these minerals. Homogenisation-temperature $\left(T_{h}\right)$ distributions reveal nearly identical successions of secondary minerals (Fig. 13). The lowest $T_{h}$ values characterise aqueous inclusions trapped in calcite, and increasingly higher values anhydrite and quartz in that order. Homogenisation temperatures for aqueous inclusions in albite and chalcedony were measured in the Namyślin 1 rock only; the values obtained are similar to those for high temperature inclusions trapped in quartz.

Comparison of $\mathrm{T}_{h}$ distribution (Fig. 13) between the three boreholes indicates that the mineral-forming processes took place in three different hydrothermal regimes. The lowest $T_{h}$ values were found in the Dzieduszyce 1 borehole and range from $130^{\circ} \mathrm{C}$ (inclusions in calcite and anhydrite) to $160^{\circ} \mathrm{C}$ (inclusions in vein quartz). Namyślin $1 \mathrm{~T}_{\mathrm{h}}$ values are intermediate and range from $130^{\circ} \mathrm{C}$ (inclusions in calcite) to $180^{\circ} \mathrm{C}$ (inclusions in vein quartz). The highest $\mathrm{T}_{\mathrm{h}}$ values, measured in Witnica 1 rock, vary from $170^{\circ} \mathrm{C}$ (inclusions in calcite) to $210^{\circ} \mathrm{C}$ (inclusions in quartz).

The salt-equivalent compositions of the aqueous inclusions were determined on the basis of cotectic and eutectic melting temperatures (see Roedder 1984 for details). The early fluids in aqueous inclusions with the lowest $T_{h}$ values were relatively dilute and $\mathrm{Na}_{2} \mathrm{SO}_{4}$-rich (Fig. 14, Table 2). Increase in $\mathrm{T}_{\mathrm{h}}$ is clearly coupled with alteration in fluid composition. The composition of the fluid progressively evolved into a chloride-rich solution and the total salinity of the fluid increased. Inclusions characterised by the highest $\mathrm{T}_{h}$ values contain $\mathrm{NaCl}$-rich fluid with the highest total salinity. 


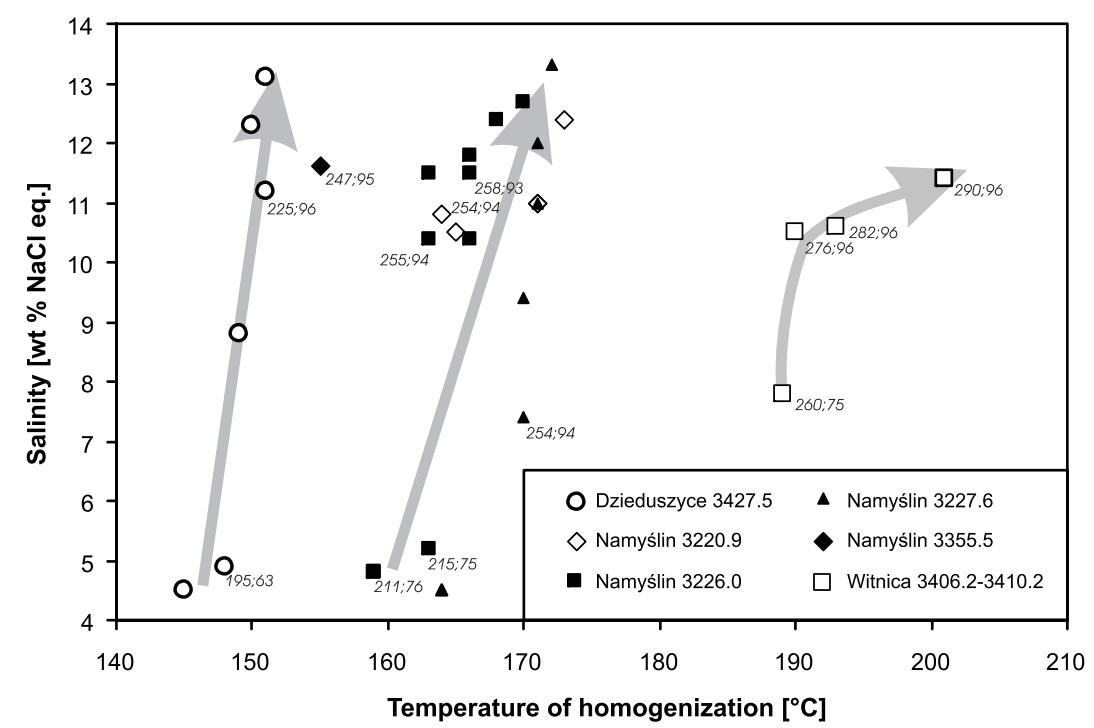

Fig. 14. Temperature of homogenization $\left(\mathrm{T}_{\mathrm{h}}\right)$ vs. salinity diagram; gray arrows denote trends of increasing salinity concurrent with increasing $\mathrm{T}_{\mathrm{h}}$; numbers denote actual entrapment temperature and pressure, respectively

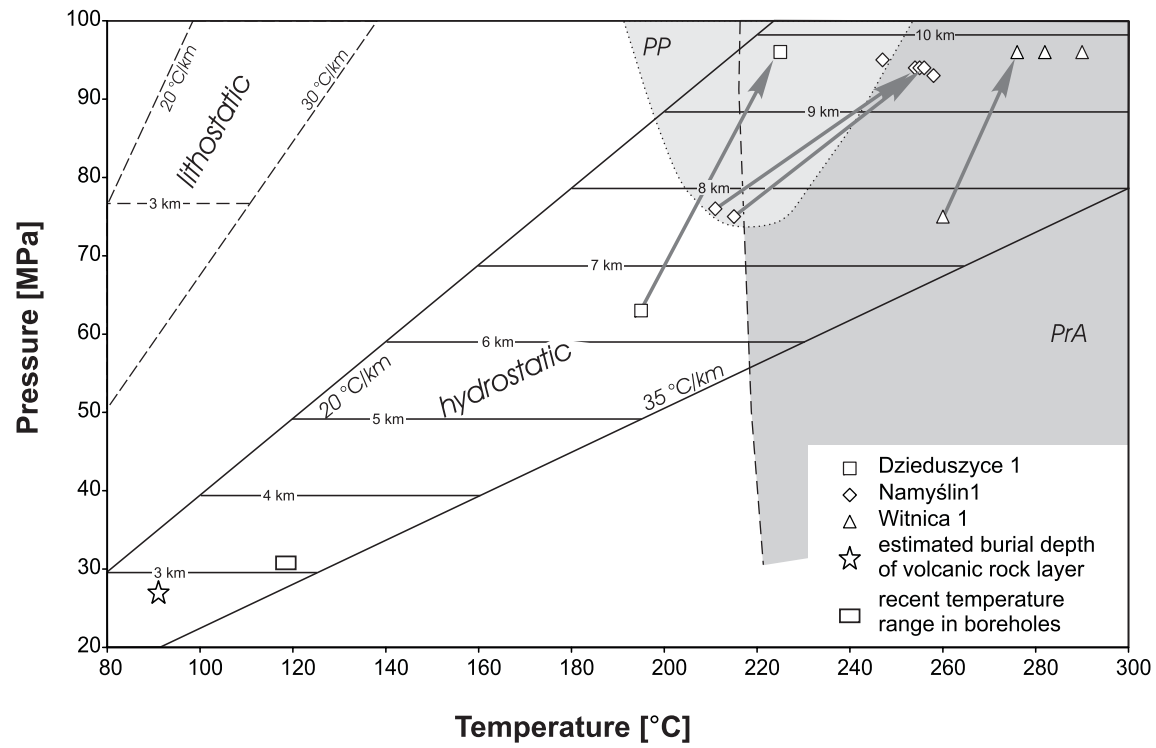

Fig. 15. P-T diagram showing fields of prehnite-pumpellyite $(P P)$ and prehnite-actinolite $(\operatorname{Pr} A)$ metamorphic subfacies (modified after Frey et al. 1991), hydrostatic and lithostatic pressure limits, and burial temperatures calculated on the basis of $20-35^{\circ} \mathrm{C} \mathrm{km}^{-1}$ geothermal gradients. Arrows join experimental data acquired from core and rim of the same quartz crystal; recent temperature ranges for the boreholes studied are courtesy of K. Dyjaczyński 
The presence of co-genetic aqueous and gaseous inclusions in quartz provides an opportunity to determine real inclusion-entrapment temperatures and pressures that correspond to actual parameters of quartz crystallization as well as to real and precise metamorphic $\mathrm{p}-\mathrm{T}$ conditions. The results of crossed isochore $\mathrm{p}-\mathrm{T}$ determinations reveal two sets of co-genetic inclusions (Fig. 15, Table 2):

1. An early low p-T group embracing Dzieduszyce 1, sample no. $2\left(195^{\circ} \mathrm{C}, 63 \mathrm{MPa}\right)$, Namyślin 1, nos. $12,13\left(211-215^{\circ} \mathrm{C}, 75-76 \mathrm{MPa}\right)$ and Witnica 1, no. 29 (260 $\mathrm{C}$, $75 \mathrm{MPa})$.

2. A late high p-T group comprising Dzieduszyce 1, no. $4\left(225^{\circ} \mathrm{C}, 96 \mathrm{MPa}\right)$, Namyślin 1 , nos. $7,14,16,22\left(247-258^{\circ} \mathrm{C}, 93-95 \mathrm{MPa}\right)$ and Witnica 1 , nos. $28,30,31\left(276-290^{\circ} \mathrm{C}\right.$, $96 \mathrm{MPa})$.

Though the entrapment temperatures scatter, the variation in the measured entrapment pressures is small, especially for the high p-T group. The limited scatter of the pressure values potentially provides an overall maximum value for the time of inclusion entrapment.

\section{K-Ar DATING}

K-Ar determinations were carried out on four coarse-grained whole-rock fractions and on one sample of vein filling. The mineral compositions of the ultrasonically treated samples comprised variable quantities of albite, K-feldspar, quartz and pumpellyite. The vein material from Dzieduszyce 1 consisted of quartz, dioctahedral mica and minor calcite.

The results of the analyses and the corresponding K-Ar ages are listed in Table 3. The amount and fraction of radiogenic ${ }^{40} \mathrm{Ar}$, and the values obtained for the GLO standard, attest to the good quality of the analyses (Table 3). The variable potassium content reflects the differing proportions of K-bearing minerals in whole-rock fractions (K-feldspar) and in the Dzieduszyce 1 vein material (mica).

The oldest radiometric age, $284 \pm 5 \mathrm{Ma}$, was obtained from the Dzieduszyce 1 whole-rock sample. In the analysed sample, K-feldspar was unequivocally the main K-bearing mineral. This result implies that K-feldspar may be a primary mineral in this rock. Empirical K-feldspar closure temperatures range from $223^{\circ} \mathrm{C}(10 \mu \mathrm{m}$ grain size; Foland 1994) up to $350^{\circ} \mathrm{C}$ (Lovera et al. 1989). In general, closure temperature depends on average grain size. The average size of K-feldspar grains from Dzieduszyce 1 exceeds $20 \mu \mathrm{m}$. As the metamorphic temperature recorded in the Dzieduszyce 1 sample was $225^{\circ} \mathrm{C}$, there is reason to suggest that the K-feldspar closure temperature was not exceeded and that Ar was not lost. Thus, the $284 \pm 5 \mathrm{Ma}$ age can be considered as a crystallization age for the extrusive rock - and the volcanicity as Early Permian.

The two Namyślin 1 samples gave similar ages - 188-190 Ma (Sinemurian-Pliensbachian). K-Ar dating of the Witnica 1 sample provided a Late Jurassic age $-149 \pm 4 \mathrm{Ma}$ (Tithonian). K-feldspar was the main K-bearing mineral in these samples. The recorded metamorphic temperatures in both sites (see above) likely exceeded the K-feldspar closure temperature causing the $\mathrm{K}$-Ar isotopic system in preserved primary K-feldspar 
K-Ar ages of the selected metavolcanic rocks from Gorzów Wielkopolski Block

\begin{tabular}{||c|c|c|c|c|c||}
\hline \multirow{2}{*}{ Locality } & $\begin{array}{c}\text { Description of sample } \\
(\text { depth, K-bearing mineral })\end{array}$ & $\begin{array}{c}\mathrm{K}_{2} \mathrm{O} \\
{[\mathrm{wt} \%]}\end{array}$ & $\begin{array}{c}{ }^{40} \mathrm{Ar}^{*} \\
{[\% \mathrm{Ar}]}\end{array}$ & $\begin{array}{c}{ }^{40} \mathrm{Ar}^{*} \\
{\left[\mathrm{pmol} \cdot \mathrm{g}^{-1}\right]}\end{array}$ & $\begin{array}{c}\text { Age } \\
{[\mathrm{Ma}]}\end{array}$ \\
\hline \hline \multirow{3}{*}{ Dzieduszyce } & $\begin{array}{c}\text { WRf }>0.1 \mathrm{~mm}, \mathrm{USC}, \\
(3427.5 \mathrm{~m}, \mathrm{~K} \text {-feldspar })\end{array}$ & 1.33 & 69.2 & 589.7 & $\mathbf{2 8 4} \pm 5$ \\
\cline { 2 - 6 } & $\begin{array}{c}\text { vein infilling } \\
(3427.5 \mathrm{~m}, \text { dioctahedral mica })\end{array}$ & 1.12 & 74.1 & 200.9 & $\mathbf{1 2 1} \pm \mathbf{2}$ \\
\hline \multirow{2}{*}{ Namyślin } & $\begin{array}{c}\text { WRf }>0.1 \mathrm{~mm}, \mathrm{USC}, \\
(3226.0 m, \mathrm{~K} \text {-feldspar })\end{array}$ & 4.09 & 59.3 & 1169.7 & $\mathbf{1 8 8} \pm \mathbf{1}$ \\
\cline { 2 - 6 } & $\begin{array}{c}\text { WRf }>0.1 \mathrm{~mm}, \mathrm{USC}, \\
(3228.0 \mathrm{~m}, \mathrm{~K} \text {-feldspar })\end{array}$ & 2.42 & 81.8 & 700.5 & $\mathbf{1 9 1} \pm \mathbf{2}$ \\
\hline \multirow{2}{*}{ Witnica } & $\begin{array}{c}\text { WRf }>0.1 \mathrm{~mm}, \mathrm{USC}, \\
(3409.3 m, \mathrm{~K} \text {-feldspar })\end{array}$ & 2.30 & 71.2 & 514.5 & $\mathbf{1 4 9} \pm \mathbf{2}$ \\
\hline
\end{tabular}

Explanations: WRf - whole-rock fraction, USC - ultrasonically cleaned, ${ }^{40} \mathrm{Ar}^{*}$ - radiogenic argon.

to be reset. The Dzieduszyce 1 sample provided the youngest age of all; this Early Cretaceous age (121 $\pm 2 \mathrm{Ma}$, Aptian) is related to crystallization of the dioctahedral mica.

\section{DISCUSSION}

\section{Volcanic extrusion age}

A large igneous province developed during the Late Carboniferous and Early Permian in northern Europe. Widespread volcanic and magmatic activity was closely associated with extensional tectonics (e.g., Neumann et al. 2004). Despite the enormous scale, intrusive and volcanic activities were irregularly distributed, occurring mainly in the Oslo graben (Norway) and its extension in Skagerrak, in Scania (S Sweden), Bornholm, the North Sea, northern Germany and in north-western Poland. Recent SHRIMP zircon age determinations of felsic volcanic rocks from the North German Basin indicate that the igneous activity there spanned a relatively short period of $c a$ 10 Ma between ca 302 and 294 Ma (Breitkreuz, Kennedy 1999) coinciding to an early stage of basin evolution. Radiometric ages for various intrusive and volcanic rocks from the Thuringian Forest and Harz Mts cluster between 307-291 Ma (Neumann et al. 2004).

In the rocks investigated, preserved igneous textures and numerous vesicles are indicative of sub-aerial lava extrusion. Their chemical composition classifies these rocks as andesite-basalts and andesites (Fig. 10A). Their minor and trace element compositions are those of within-plate subalkaline basalts. The minor and trace elements also suggest significant crustal contamination of the protolith (Dubińska et al. 2004a). 
The K-Ar age of $c a 285$ Ma reported above makes the extrusion of the andesitic rocks in the Gorzów Wielkopolski area the youngest dated volcanic episode of the Wyrzeka Formation ( $c f$. Karnkowski 1999). This age also suggests that the eruption was the latest volcanic episode in the eastern margin of the North German Basin during the Early Permian. The coeval Września IG-1 tuff ( $288 \pm 5$ Ma; Lippolt et al. 1982) serves to confirm widespread coeval volcanic activity, notwithstanding the geochemical differences. The geochemical signature of the andesitic rocks examined here also compares with that of the East Brandenburg andesites (Benek et al. 1996). The implication is that all of the aforementioned volcanic rocks belong to the same period of volcanic activity.

\section{Metamorphic process: conditions and age}

Mafic rocks described from the North German Basin exhibit different degrees of metamorphic alteration (e.g., Marx et al. 1995; Benek et al. 1996; Brecht 1999; Dubińska et al. 2004a; Paulick, Breitkreuz 2005). Permian mafic rocks from NW Poland also range in degree of alteration; some are nearly fresh, others thoroughly altered (e.g., Sadowski, Madej 2001; Dubińska et al. 2004a). The rocks that are the focus of this paper are almost completely altered. Preserved primary igneous textures and pseudomorphs after primary minerals coexist with an abundance of hydrous secondary minerals in vesicles and veinlets that are indicative of fluid - rock interaction. The main metamorphic assemblage is corrensite (quasi-ordered interstratified chlorite-smectite), laumontite, prehnite and pumpellyite. The crystallization of the main metamorphic minerals was accompanied by intensive albitization of primary plagioclase and the formation of secondary quartz, anhydrite, and titanite. Calcite and chalcedony represent the youngest phase of this alteration. The bulk-rock geochemistry suggests significant gain of $\mathrm{Si}, \mathrm{Mg}$ and $\mathrm{Ca}$ and the simultaneous loss of $\mathrm{Al}$ (Figs 10-12). A tentative explanation is that these changes were caused by the inflow of silica-rich $\mathrm{Ca}$ - and $\mathrm{Mg}$-bearing brines. These brines, simultaneously removed $\mathrm{Al}$ released from plagioclase during albitization.

Corrensite, laumontite, prehnite, and pumpellyite are typical zeolite-facies metamorphic phases formed as a result of the replacement of primary silicates in mafic igneous rocks (e.g., Liou et al. 1985; Digel, Gordon 1995; Früh-Green et al. 1996; Teagle et al. 1996; Carr et al. 1999; Schiffman, Day 1999). Bakht (2000) described the range of laumontite appearance in hydrothermally altered basalts in the Krafla geothermal field (NE Iceland) - first appearing at $120^{\circ} \mathrm{C}$ at a depth of $\mathrm{ca} 150 \mathrm{~m}$ and vanishing at $230^{\circ} \mathrm{C}$ at $450 \mathrm{~m}$. Laumontite has also been noted at temperatures as low as $50^{\circ} \mathrm{C}$ at depths of 1-3 km (Boles, Coombs 1977; Jove, Hacker 1997). Mineralogical studies in the geothermal fields at Wairakai in New Zealand (Steiner 1977) and at Reyđarfjörđur on Iceland (Liou et al. 1987) indicate that the maximum temperature for laumontite stability is $\mathrm{ca} 230^{\circ} \mathrm{C}$. Based on thermodynamic data for the NCASH system and $\mathrm{p}\left(\mathrm{H}^{2} \mathrm{O}\right)=\mathrm{p}_{\text {total }}$, Mihalynuk and Ghent (1996) calculated lower- and upper stability limits for laumontite at $160-185^{\circ} \mathrm{C}(100 \mathrm{MPa})$ and $235-270^{\circ} \mathrm{C}(200 \mathrm{MPa})$, respectively. In the Tendaho geothermal system in Ethiopia, Gianelli et al. (1998) found laumontite in altered volcanic rocks at temperatures over $270^{\circ} \mathrm{C}$; their thermodynamic calculations show the maximum temperature of laumontite occurrence to be $250^{\circ} \mathrm{C}$. 
Interlayered chlorite-smectite minerals are commonly present in active geothermal fields at temperatures $\mathrm{ca} 200^{\circ} \mathrm{C}$ (e.g., Schiffman, Fridleifsson 1991; Beaufort et al. 1995). Nouraliee (2000) noted that chlorite-smectite minerals appeared within the temperature range $200-230^{\circ} \mathrm{C}$ in the Nesjavellir geothermal area (Iceland). Chlorite-smectite minerals were recorded in the Krafla geothermal field between $220-260^{\circ} \mathrm{C}$ and corrensite in the narrow range of $230-250^{\circ} \mathrm{C}$ (Bakht 2000). However, hydrothermal corrensite associated with chlorite can form at temperatures as high as $c a 300^{\circ} \mathrm{C}$ (Dubińska et al. 2004b). In geothermal fields, discrete chlorite is usually noted in mafic rocks altered at temperatures exceeding $230^{\circ} \mathrm{C}$ (Bakht 2000; Nouraliee 2000).

Stability fields for prehnite and pumpellyite are not well defined due to their sensitivity to the chemical variation of their respective solid solution series. In low-grade metavolcanic rocks, pumpellyite usually shows a wide range of chemical compositions that do not reflect the parent-rock chemical composition. Pumpellyite composition is controlled by local environment, in particular the proximity and quantity of Fe-rich primary minerals (e.g., Cho, Liou 1987; Cortesogno et al. 1984; Schiffman, Day 1999). Based on thermodynamic calculations, Frey et al. (1991) showed that pumpellyite is stable between $100-350^{\circ} \mathrm{C}$ and $100-950 \mathrm{MPa}$ whereas prehnite is stable between $170-320^{\circ} \mathrm{C}$ at pressures up to $450 \mathrm{MPa}$. In the Reykjanes geothermal field (Iceland), prehnite may form at temperatures below $200^{\circ} \mathrm{C}$ (Tomassón, Kristmannsdóttir 1972). Teklemariam et al. (1996) described the formation of prehnite at temperatures between $285-320^{\circ} \mathrm{C}$. Coexisting prehnite and pumpellyite suggests metamorphic temperatures of $250-300^{\circ} \mathrm{C}$ (e.g., Schiffman, Liou 1980; Digel, Gordon 1995). However, $\mathrm{CO}_{2}$-rich fluids can suppress the formation of laumontite, prehnite, and pumpellyite and can result in the formation of chlorite-smectite assemblages (Bevins et al. 1991).

The maximum temperature of laumontite stability and the minimum temperature for prehnite and chlorite-smectite formation are key parameters. Combined, they suggest that the main stage of the low-grade metamorphism in the metavolcanic rocks of the Gorzów Wielkopolski Block occurred between $\sim 200-250^{\circ} \mathrm{C}$. The fluid-inclusion entrapment temperatures and pressures indicate that the metamorphic-hydrothermal process continued within the ranges $195-260^{\circ} \mathrm{C}$ and $63-96 \mathrm{MPa}$. Within this $\mathrm{p}-\mathrm{T}$ range, most of the metamorphic minerals, i.e., corrensite, pumpellyite, laumontite and prehnite crystallized during interaction between andesitic rock and low-salinity $\mathrm{Na}_{2} \mathrm{SO}_{4}$-rich fluids. The progressive change in fluid composition, including the increasing total salinity and $\mathrm{NaCl}$ contents, most probably reflects the mixing of ascending fluids with Zechstein pore waters and with soluble metamorphic reaction products.

The occurrence of calcite as a late amygdale- and veinlet-filling mineral implies that the inflow of $\mathrm{CO}_{2}$-rich fluids suppressed crystallization of calc-silicate minerals, e.g., pumpellyite, Ca-rich zeolites. P-T metamorphic conditions, as revealed by fluid inclusions in Witnica 1, range from $260-290^{\circ} \mathrm{C}$ and from $75-96 \mathrm{MPa}$. However, this metamorphic event did not result in the crystallization of typical metamorphic phases such as epidote and/or actinolite. Metamorphic disequilibrium on a local scale and/or the rapid inflow of hot $\mathrm{CO}_{2}$-rich fluids may provide the explanation.

The K-Ar age data reveal three Mesozoic events that can be keyed to the metamorphism: Aptian (121 \pm 2 Ma, Dzieduszyce 1), Sinemurian-Pliensbachian (188-190 Ma, 
Namyślin 1) and Tithonian (149 $\pm 4 \mathrm{Ma}$, Witnica 1). The ages compare with Mesozoic ages frequently reported from altered volcanic- and clastic rocks in E Germany and Poland (e.g., Brecht 1999; Maliszewska 1997). The age of the Namyślin 1 metamorphic event ( $c f$. Figs 2 and 16) is similar to ages of illite crystallization in the Penkun metavolcanic rocks of E Germany (Brecht 1999), of hydrothermal alteration in the Filipowice Permian tuff in S Poland (Michalik et al. 2003) and of pore-filling illite crystallization in Rudna Weissliegend sandstones, SW Poland (Michalik 2001). The age of the metamorphic event observed in Witnica 1 is similar (within analytical error) to the age of late-hydrothermal illite generation at Penkun (Brecht 1999) and to that of authigenic illite growth in the Wielkopolska Rotliegend sandstones (Objezierze IG-1 and Środa IG-3; Maliszewska 1997). The youngest metamorphic event revealed in Dzieduszyce 1 is close to that deemed a diagenetic illite age reported from the Rotliegend sandstone (Września IG-1; Maliszewska 1997).

The K-Ar ages fall easily into what is a nearly continuous age spectrum of hydrothermal events elsewhere (Figs 2 and 16). These events include authigenic illite crystallization in Carboniferous and Permian clastic rocks (Maliszewska 1997; Bechtel et al. 1999; Oszczepalski 1999; Zwingmann et al. 1999; Liewig, Clauer 2000; Michalik 2001; Kozłowska and Poprawa 2004; Górniak et al. 2004 and Protas 2004). The K-Ar ages also accord with those of hydrothermal alteration in Permian volcanogenic rocks (Brecht 1999; Goll et al. 2003; Michalik et al. 2003, 2004) and with those of numerous hydrothermal veins and ore deposits (Boness et al. 1990; Bechtel et al. 1999; Oszczepalski 1999; Heijlin et al. 2003; Schneider et al. 2003 and Schmidt-Mumm, Wolfgramm 2004).

The hydrothermal processes that took place in the North German- and Polish Basins seem to have been contemporaneous with the Triassic - Late Cretaceous thermal

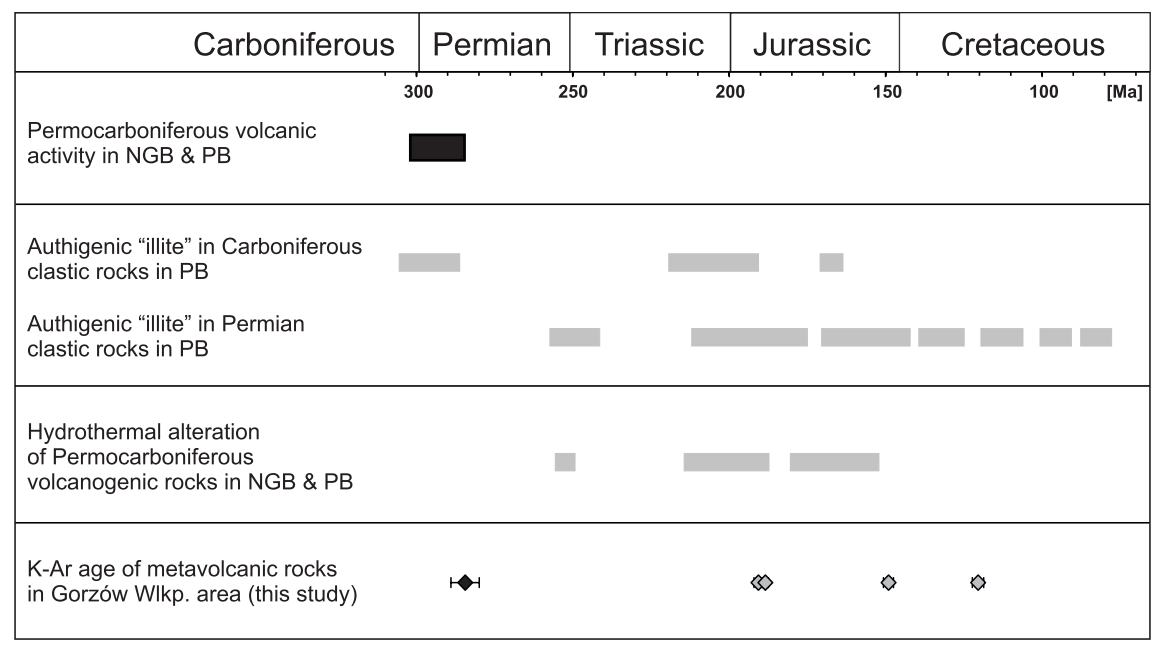

Fig. 16. Summary diagram of radiometric ages of mineral-forming events. Diamonds (with error bars) show measured K-Ar ages for the samples studied. Rectangles enclose compiled age ranges; black filling - volcanic events, gray - alteration or authigenic illite ages. Abbreviations: NGB - North German Basin, PB - Polish Basin; see text and Fig. 2 for details 
subsidence and regional extension of these basins (e.g., Scheck-Wenderoth, Lamarche 2005). The hydrothermal activities presumably ceased with the beginning of Late Cretaceous-Early Tertiary basement inversion and basin uplift (cf. Michalik 2001 and Mazur et al. 2005). Schmidt-Mumm and Wolfgramm (2002) suggest that Mesozoic hydrothermal activity in the North German Basin was linked to widespread fluid migration through faults and fractures activated and developed during subsidence and extension. The coincidence of the metamorphic ages reported in the present paper and the age span of regional Mesozoic hydrothermal activity suggests, at the very least, a similar hydrothermal origin for the metamorphism in the Gorzów Wielkopolski area.

The metamorphic process: an explanation

Available data on the subsidence of the Polish Basin and its history of sedimentation suggest that the top of the volcanic layer is between 2330-2700 m below ground (Table 4; see also Juskowiak-Schoeneichowa 1979; Marek, Pajchlowa 1997; Karnkowski 1999; Majorowicz et al. 2003; Majorowicz 2004; Vosteen et al. 2004; Lamarche, Scheck-Wenderoth 2005). Taking the Mesozoic heat flow calculations of Karnkowski (1999) into account and assuming a hydrostatic pressure (see, e.g., Huenges et al. 1997; Shmonov et al. 2002), the burial temperature and the formation pressure may be estimated at $85-92^{\circ} \mathrm{C}$ and $25-26 \mathrm{MPa}$, respectively. These values are considerably lower than might be deduced from the observed degree of metamorphism. The measured metamorphic temperatures are $c a$ 2.5-3 times higher than the estimated burial temperature. The measured metamorphic pressures exceed, by 3.5-4 times, the estimated formation pressure and suggest an unrealistic $10 \mathrm{~km}$ depth of burial (Fig. 15). Calculated geothermal gradients ranging between $83-124^{\circ} \mathrm{C} \cdot \mathrm{km}^{-1}$ suggest either a large

TABLE 4

Actual and estimated depths, pressures and temperatures during metamorphic episodes

\begin{tabular}{||l|c|c|c||}
\hline \multicolumn{1}{|c|}{ Borehole } & Dzieduszyce & Namyślin & Witnica \\
\hline \hline Recent sampling depth (andesite) $[\mathrm{m}]$ & 3427 & $3226-3228$ & 3410 \\
\hline Metamorphic temperature $\left[{ }^{\circ} \mathrm{C}\right]$ & 225 & 258 & 290 \\
\hline Metamorphic pressure $[\mathrm{MPa}]$ & 96 & 94 & 96 \\
\hline Age of metamorphic event $[\mathrm{Ma}]$ & $121 \pm 2$ & $188-191$ & $149 \pm 2$ \\
\hline \multicolumn{4}{|c|}{ Estimations } \\
\hline Depth to top of volcanic layer $[\mathrm{m}]$ & $2500-2700$ & $2330-2500$ & $2330-2500$ \\
\hline Hydrostatic pressure $[\mathrm{MPa}]$ & $26 \pm 2$ & $25 \pm 2$ & $25 \pm 2$ \\
\hline Burial temperature $\left[{ }^{\circ} \mathrm{C}\right]$ & $85 \pm 3$ & $92 \pm 3$ & $92 \pm 3$ \\
\hline
\end{tabular}

All estimations are based on following sources: Juskowiak-Schoeneichowa (1979), Karnkowski (1999), Lamarche and Scheck-Wenderoth (2005), Majorowicz et al. (2003), Majorowicz (2004), Vosteen et al. (2004). 
intrusion nearby or a developing rift. This large discrepancy between the estimated burial parameters and the measured metamorphic $\mathrm{p}$-T conditions needs explanation.

Four possible models or eventualities that might explain the discrepancy are considered: 1) exothermic metamorphic reactions, 2) convection-driven upwelling fluid flow, 3) igneous rock intrusion and 4) fracture flow (Fig. 17). Simple approximations used (model 1) and estimations based on 2D numerical modelling (models 2-4) are evaluated below.
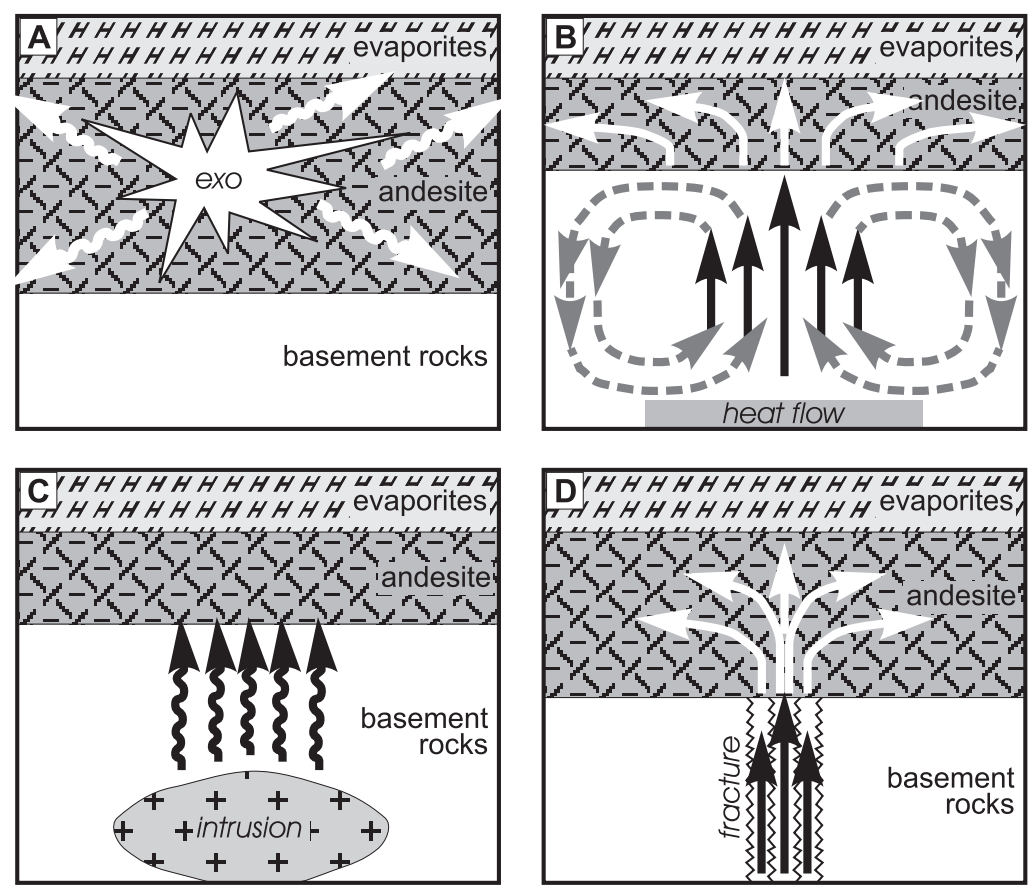

Fig. 17. Cartoons illustrating four possible metamorphic models. A. Exothermic metamorphic reactions.

B. Convection-driven upwelling fluid flow. C. Intrusion of igneous rocks. D. Fracture flow

The numerical modelling is based on the HYDROTHERM program (Hayba, Ingebritsen 1994). This program is a finite-difference model for three-dimensional, multiphase flow of pure water and heat over a temperature range from $0-1200^{\circ} \mathrm{C}$ and a pressure range from $0.05 \mathrm{MPa}$ to $1 \mathrm{GPa}$. It provides numerical approximations to mass- and energy-balance equations that are posed in terms of pressure and enthalpy. Major assumptions are: 1) the rock matrix can be treated as a porous medium, 2) water and rock are in thermal equilibrium, 3) capillary pressure is negligible, 4) the circulating fluid is pure water, 5) a two-phase form of Darcy's Law is valid and 6) heat transfer by dispersion and radiation is negligible (Hayba, Ingebritsen 1994).

The modelling results show only what may be termed fluid-rock interaction tendencies. However, even rough estimations may help to discriminate between the various models. The aim is to find a model that would generate a $\mathrm{p}-\mathrm{T}$ curve embracing all p-T points obtained for each rock sample. The general model comprises a $27 \mathrm{~km}$ wide (x) and a $18 \mathrm{~km}$ deep (z) 2D section composed of six parallel rock layers. From top 
Physical parameters assigned to the model layers

\begin{tabular}{||l|c|c|c|c|c|c||}
\hline \multicolumn{1}{|c|}{ Layer (abbreviation) } & $\begin{array}{c}\text { Permeability } \\
{\left[\mathrm{m}^{2}\right]}\end{array}$ & Porosity & $\begin{array}{c}\text { Density } \\
{\left[\mathrm{kg} \cdot \mathrm{m}^{-3}\right]}\end{array}$ & $\begin{array}{c}\text { Heat } \\
\text { capacity } \\
{\left[\mathrm{J} \cdot(\mathrm{kg} \cdot \mathrm{K})^{-1}\right]}\end{array}$ & $\begin{array}{c}\text { Heat } \\
\text { conductivity } \\
{\left[\mathrm{W} \cdot(\mathrm{m} \cdot \mathrm{K})^{-1}\right]}\end{array}$ & Source \\
\hline \hline Mesozoic $(\mathrm{M})$ & $10^{-13}$ & 0.13 & 2700 & 1180 & 2.0 & $(1)$, modified \\
\hline Permian - Zechstein $(\mathrm{Pz})$ & $10^{-19}$ & 0.001 & 2160 & 840 & 3.5 & $(1,2)$ \\
\hline Permian - volcanic $(\mathrm{Pv})$ & $\begin{array}{c}10^{-13}(x) \\
10^{-17}(z)\end{array}$ & 0.06 & 2670 & 1000 & 2.4 & $(1)$ \\
\hline Older Paleozoic $(\mathrm{OP})$ & $10^{-16}$ & 0.08 & 2650 & 1000 & 2.3 & $(1,3)$ \\
\hline Metamorphic 2 $\left(\mathrm{m}_{2}\right)$ & $10^{-19}$ & 0.01 & 2650 & 1000 & 2.5 & $(1,3)$ \\
\hline Metamorphic $1\left(\mathrm{~m}_{1}\right)$ & $10^{-19}$ & 0.001 & 2650 & 1000 & 2.5 & $(1,3)$ \\
\hline Fracture & $\begin{array}{c}10^{-16}(x) \\
10^{-09}(z)\end{array}$ & 0.10 & 2650 & 1000 & 2.0 & $(1,4)$, modified \\
\hline Seal & $10^{-30}$ & 0.0001 & 2650 & 1000 & 2.0 & $(1,4)$, modified \\
\hline
\end{tabular}

Sources: (1) - Magri et al. (2005), (2) - Polyansky et al. (2003), (3) - Manning and Ingebritsen (1999), (4) - Jourde et al. (2002).

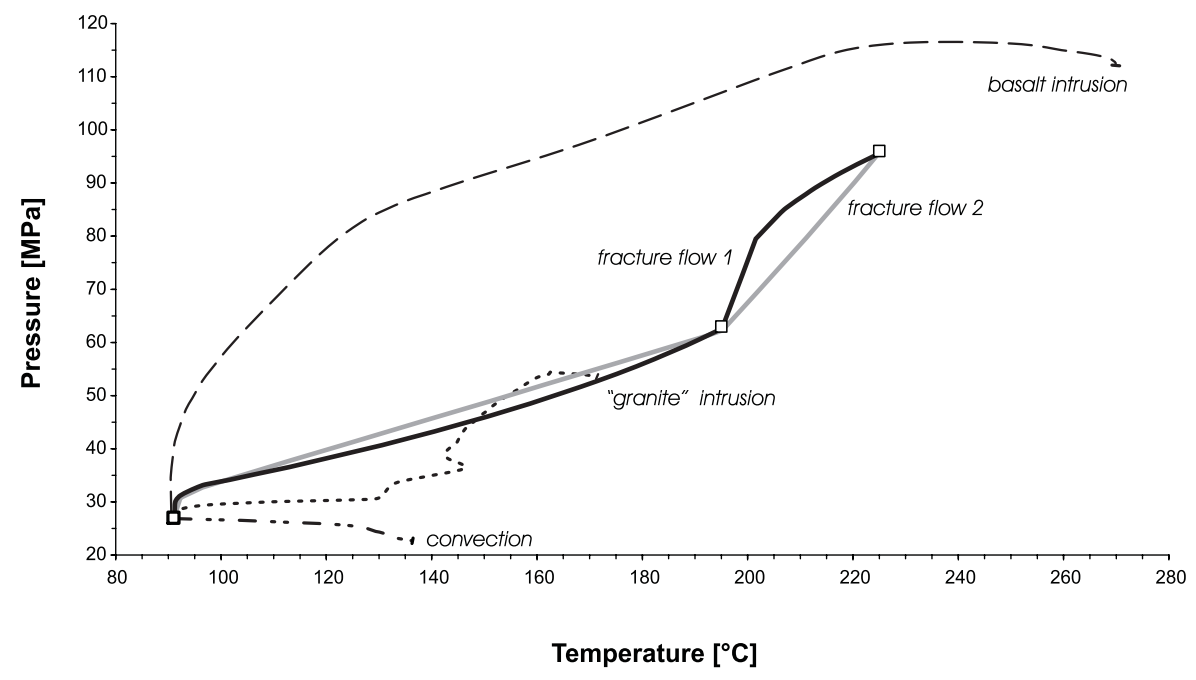

Fig. 18. Calculated pressure vs. temperature trajectories based on the models presented in Figure 17 B-D. All curves involve an observation point located within the upper central part of the volcanic layer. Data points are entrapment p-T conditions measured in Dzieduszyce 1 (3427.5 m) and to estimated burial $\mathrm{p}-\mathrm{T}$ conditions 
down, these are: 1) the Mesozoic sedimentary complex (Mz; thickness $(\mathrm{h})=1.5 \mathrm{~km})$, 2) the Permian (Zechstein) evaporitic formation $(\mathrm{Pz} ; \mathrm{h}=1 \mathrm{~km}), 3)$ the Permian volcanic layer $(\mathrm{Pv} ; \mathrm{h}=0.5 \mathrm{~km}), 4)$ the older Palaeozoic sedimentary complex $(\mathrm{OP} ; \mathrm{h}=5 \mathrm{~km})$, 5) weakly metamorphosed rocks $\left(\mathrm{m}_{2} ; \mathrm{h}=7 \mathrm{~km}\right)$ and 6 ) highly metamorphosed rocks $\left(\mathrm{m}_{1} ; \mathrm{h}=3 \mathrm{~km}\right)$. Model layer thicknesses are based on deep seismic profiles (Jensen et al. 1999; Janik et al. 2002; Winchester et al. 2003) and on reconstructions of sedimentation and subsidence (Juskowiak-Schoeneichowa 1979; Karnkowski 1999; Stephenson et al. 2003; Brink 2005; Lamarche, Scheck-Wenderoth 2005). The physical parameters of the layers are given in Table 5 . The hydrostatic gradient was assumed to be the vertical pressure gradient though this assumption considerably limits model applicability to a depth of $9 \mathrm{~km}$ (see Huenges et al. 1997). Pressure-temperature progression curves corresponding to the observation point located in the central upper part of the Permian volcanic layer are given in Figure 18 and snapshots of the pressure and temperature fields are shown in Figure 19. The results obtained are only rough approximations due to the various assumptions made and the simplicity of the model.

\section{Model 1. Exothermic metamorphic reactions}

Theoretical considerations by Haack and Zimmermann (1996) are the basis for this model (Fig. 17A). Numerous thermodynamic estimations of hydration metamorphic reactions, in particular the exothermic hydration of anhydrous silicates, reveal significant excess energy. For example, one cubic meter of volcanic rock, e.g., basalt or andesite, can produce roughly $60 \mathrm{MJ}$ of heat (enthalpy) during the incorporation of $1 \mathrm{wt} \%$ of pure water (Haack, Zimmermann 1996). Based on the assumption that the metavolcanic rocks had between 3-7 $\mathrm{wt} \%$ bound water, the estimated total heat production can range between $180-420 \mathrm{MJ}$ per $\mathrm{m}^{3}$ of reacting rock. This amount of energy could increase the temperature of the reacting rock by $c a 70-160^{\circ} \mathrm{C}$ assuming complete thermal isolation from its surroundings (see Table 5). However, the released heat would be dissipated through conductive (and/or advective) heating of the adjacent rock layers and/or by passing fluids. If all the heat were to be dissipated completely and isotropically into the adjacent rock (consisting of $26 \times 1 \mathrm{~m}^{3}$ rock cubes), the average temperature of the whole block $\left(27 \mathrm{~m}^{3}\right)$ would only increase by $c a 3.5-8^{\circ} \mathrm{C}$. The calculations suggest that exothermic metamorphic reactions play a limited role. However, the heat released during the metamorphic process could supply an appreciable amount of energy to the immediate surroundings - initiating metamorphism perhaps and helping to sustain reactions already active.

\section{Model 2. Convection-driven upwelling fluid flow}

The model (Fig. 17B) is based on the well-documented occurrence of geological-scale convection cells in large permeable rock formations. For example, Magri et al. (2005) have demonstrated large-scale, temperature-driven convection of salt brines in the North German Basin - a process still active there and causing salt brines to reach the surface in some areas However, their calculations (op. cit.) show that convection 
cannot be the sole driving force. Wisian and Blackwell (2004) opined that topography and geological structure could provide an additional impetus sustaining convection. In a thorough study on diagenesis in the Weissliegend sandstones, Michalik (2001) showed that Mesozoic fluid convection was responsible for illite crystallization and for the development of $\mathrm{Cu}$ ores.

To test the convection model, a permanent heat flow of $70 \mathrm{~mW} \cdot \mathrm{m}^{-2}$ (Karnkowski $1999)$ at the bottom of the general layered model was visualised. Calculations show convection cells, each 8-10 km wide, circulating inside the older Palaeozoic (OP) and Permian volcanic (Pv) layers of the model (Fig. 19A). The Pv layer reaches a maximum

\section{Temperature}

Pressure
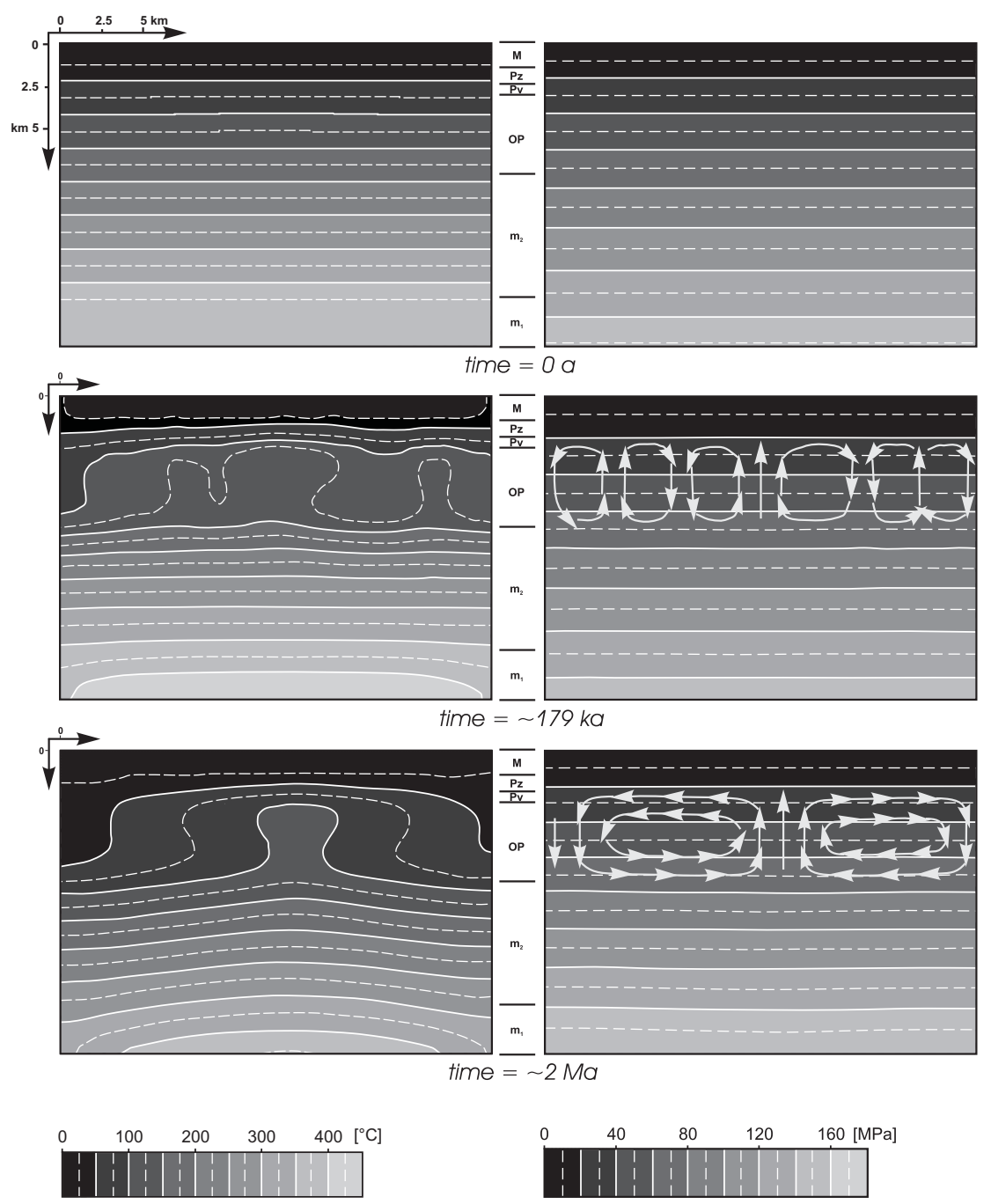

Fig. 19A. Computed pressure and temperature spatial distributions Convection-driven upwelling fluid flow model; white arrows directions of convecting fluid streams 
temperature of $c a 136^{\circ} \mathrm{C}$ after ca $179 \mathrm{ka}$ ( $c f$. Fig. 18). The modelled temperature distribution along the $\mathrm{Pv}$ layer is non-uniform and ranges between ca $75-130^{\circ} \mathrm{C}$. After $\mathrm{ca}$ $2 \mathrm{Ma}$, a large $27 \mathrm{~km}$ wide convection cell forms. The temperature distribution along the volcanic layer is still inhomogeneous and ranges between $40-70^{\circ} \mathrm{C}$. Fluid pressure falls from 26 to $21 \mathrm{MPa}$ due to the thermal expansion (density decrease) of water. The model pressure remains nearly uniform. This model does not fit the known geology.

\section{Model 3. Intrusion of igneous rocks}

Carr et al. (1999) considered that low-grade metamorphism of mafic volcanic lavas in the Broughton Formation (Sydney Basin, Australia) was due to a large buried intrusion also potentially responsible for coal metamorphism in the southern Sydney Basin. Polyansky et al. (2003) modelled fluid flow and steam-water transition in the vicinity of a cooling basalt sill intruded into limestone. They showed that heat dissipated from the cooling intrusion was responsible for the conversion of kerogen into gaseous and liquid hydrocarbons.

Two variations of Model 3 were considered. The first envisages an intrusion into the $\mathrm{m}_{1}$ metamorphic layer (Fig. 19B). The temperature of the intrusion is taken to be $900^{\circ} \mathrm{C}$ (see Table 5 for other physical parameters) and the heat flow at the bottom of the layer to be $220 \mathrm{~mW} \cdot \mathrm{m}^{-2}$ over $10 \mathrm{ka}$. Any effects of fluid discharge, cooling and devolatilization were ignored.

Calculations reveal that after $\mathrm{ca} 25 \mathrm{ka}$, a series of very unstable $2 \mathrm{~km}$ wide convection cells in the OP and Pv layers result in significant variation of the p-T curve (Figs 18 and 19B). A large convection cell (27 km wide) develops after ca $660 \mathrm{ka}$ and the Pv layer reaches a maximum temperature of $c a 171^{\circ} \mathrm{C}$. Fluid pressure distribution remains homogeneous. Pressure increases in the Pv layer up to ca $51 \mathrm{MPa}$. However, the model temperature and pressure remains below the measured values.

The second variation of the model illustrates the effects of heat dissipation from a cooling basaltic sill $\mathrm{ca} 1 \mathrm{~km}$ thick and $18 \mathrm{~km}$ wide emplaced between the OP and the $\mathrm{m}_{2}$ layers (Fig. 19C). Any effects of fluid discharge were ignored. The temperature of the model intrusion was taken to be $1000^{\circ} \mathrm{C}$. Other physical parameters were as those of the Pv layer as given on Table 5. At ca $74 \mathrm{ka}$, the maximum model temperature in the Pv layer reaches $c a 270^{\circ} \mathrm{C}$. However, the maximum pressure of $c a 116 \mathrm{MPa}$ in this layer is reached $22 \mathrm{ka}$ earlier (Fig. 18). The fluid pressure distribution remains uniform though it significantly exceeds the appropriate lithostatic pressures; the Mesozoic layer (Mz) is the exception due to the sealing properties of the Zechstein layer (Pz). The model pressures and temperatures are significantly higher than the measured values. The model strongly suggests that intrusion was unlikely to offer an explanation for the observed low-grade metamorphism.

\section{Model 4. Fracture flow}

Fractures are a common feature of the rock complexes. Fracture-induced permeability is an important factor to be taken into account in any regional geothermal and 


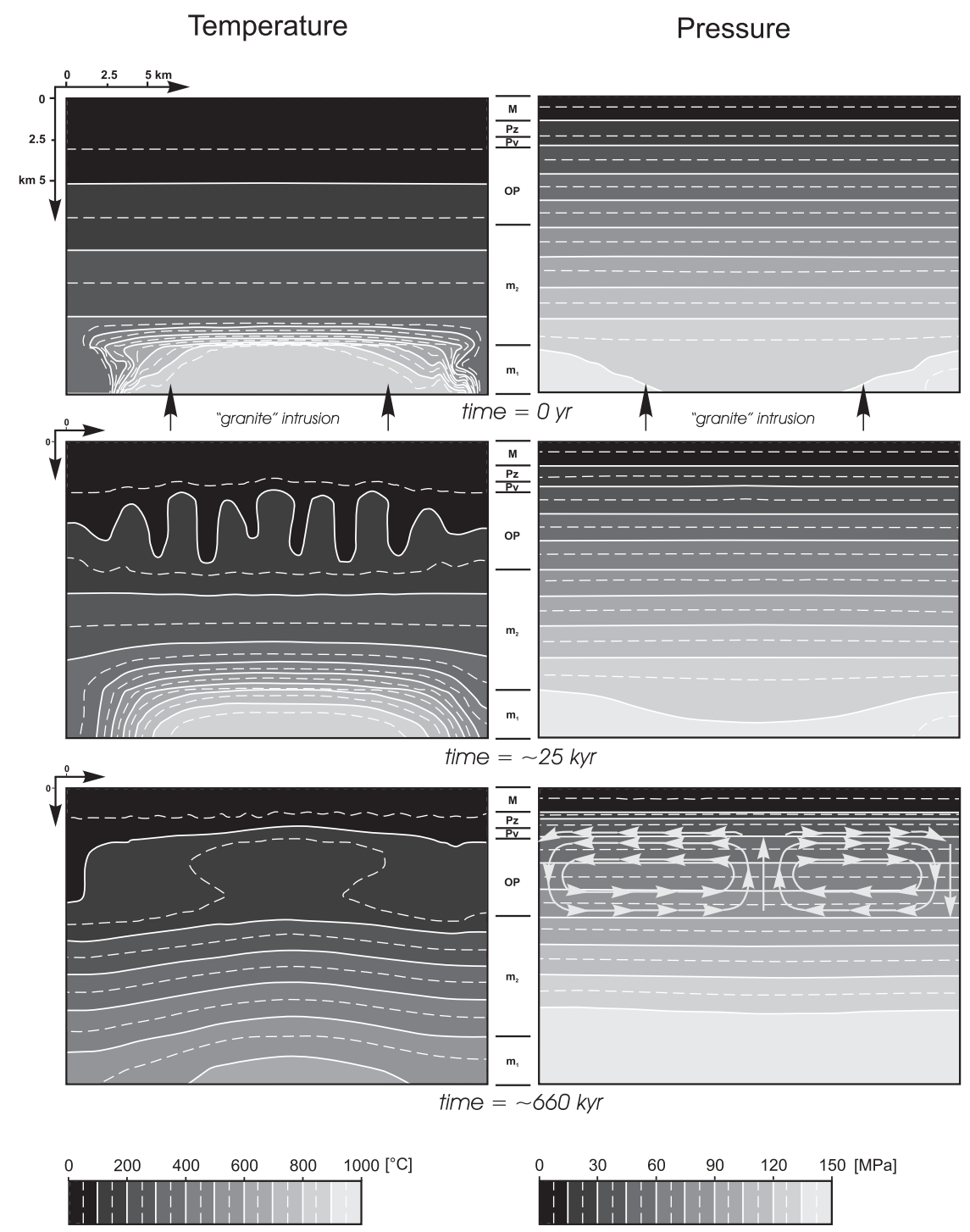

Fig. 19B. Computed pressure and temperature spatial distributions Deep-seated intrusion model; black arrows point to base limits of the model intrusion

geochemical study (e.g., Oliver 2001; Wangen, Munz 2004). Consideration was given to a fracture-flow model as there are faults in the Permian volcanic rock basement (Fig. 3).

There are several Mesozoic vein occurrences in the North German Basin (Schneider et al. 2003 and references therein). Moreover, the origins of two major metal ore deposits in the Polish Basin, i.e. the Upper Silesian $\mathrm{Zn}-\mathrm{Pb}$ deposits and the Lower Silesian $\mathrm{Cu}$ ore deposit, are usually considered to be related to fracture-controlled Mesozoic hydrothermal activity (Blundell et al. 2003; Heijlen et al. 2003). The presence of deeply penetrating faults is indicated by high levels of helium in the natural gas 


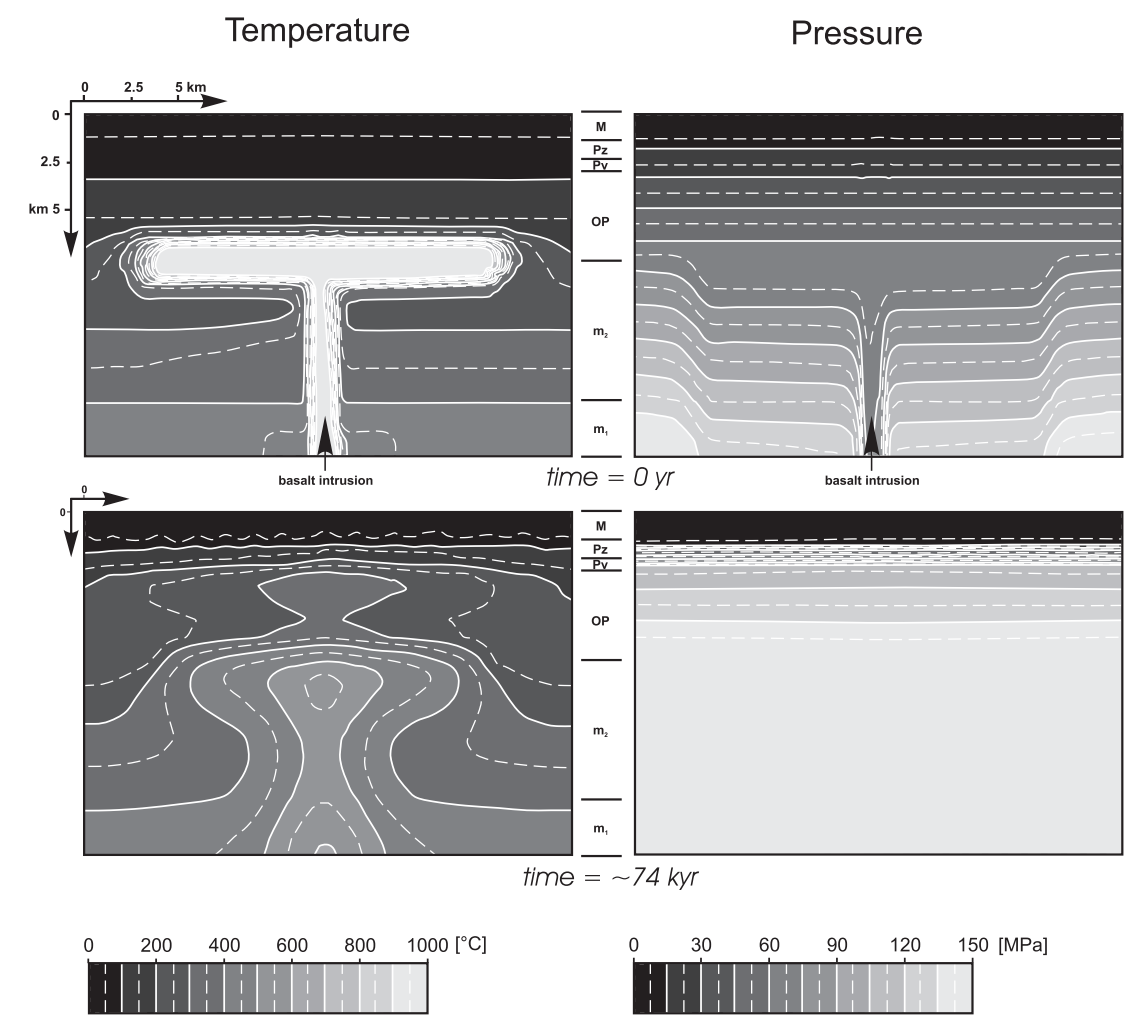

Fig. 19C. Computed pressure and temperature spatial distributions Shallow intrusion model; black arrow marks inlet of model basalt dyke

deposits of the Polish Basin (e.g., Karnkowski 1999) and by the mantle isotopic signature of the helium ( $c a 10 \mathrm{R} / \mathrm{R}_{\mathrm{A}}$; Blundell et al. 2003; W. Kempiński pers. comm.).

The basic model involves a vertical fracture extending from the basement up to the middle of Pv layer. This fracture consists of a permeable core layer coated by sealing rims that reach the OP-Pv boundary only (see Table 5). The structure of the fault is as in Jourde et al. (2002). The generation of frictional heat and any abnormal pore pressure during faulting is discounted because of the extensional style of the Mesozoic regional tectonics and because of the absence of local thrusts (e.g., Smith, Wiltschko 1996; Scheck, Bayer 1999; Ziegler 2005). The fluid source is located at the bottom of the model within the fracture layer. The model source temperature is $600^{\circ} \mathrm{C}-$ the temperature of fluid released from rocks altered at a depth corresponding to amphibolite-facies metamorphism. The flow rate of the source is a fitting variable.

Two model variations were considered. The first examines the effects of hot fluid inflow into the Permian volcanic layer (Pv), which is hydraulically open (Fig. 19D). The best fit is attained with a two-stage flow-rate profile: Stage $1-7 \mathrm{~kg} \cdot \mathrm{s}^{-1}$ over 750 years and Stage $2-75 \mathrm{~kg} \cdot \mathrm{s}^{-1}$ over 30 years. The $\mathrm{p}-\mathrm{T}$ curve fits three points representing the burial temperature and two metamorphic episodes (Fig. 18). The maximum expected temperature in the Pv layer is reached after ca 780 years. The area of increased temperature 


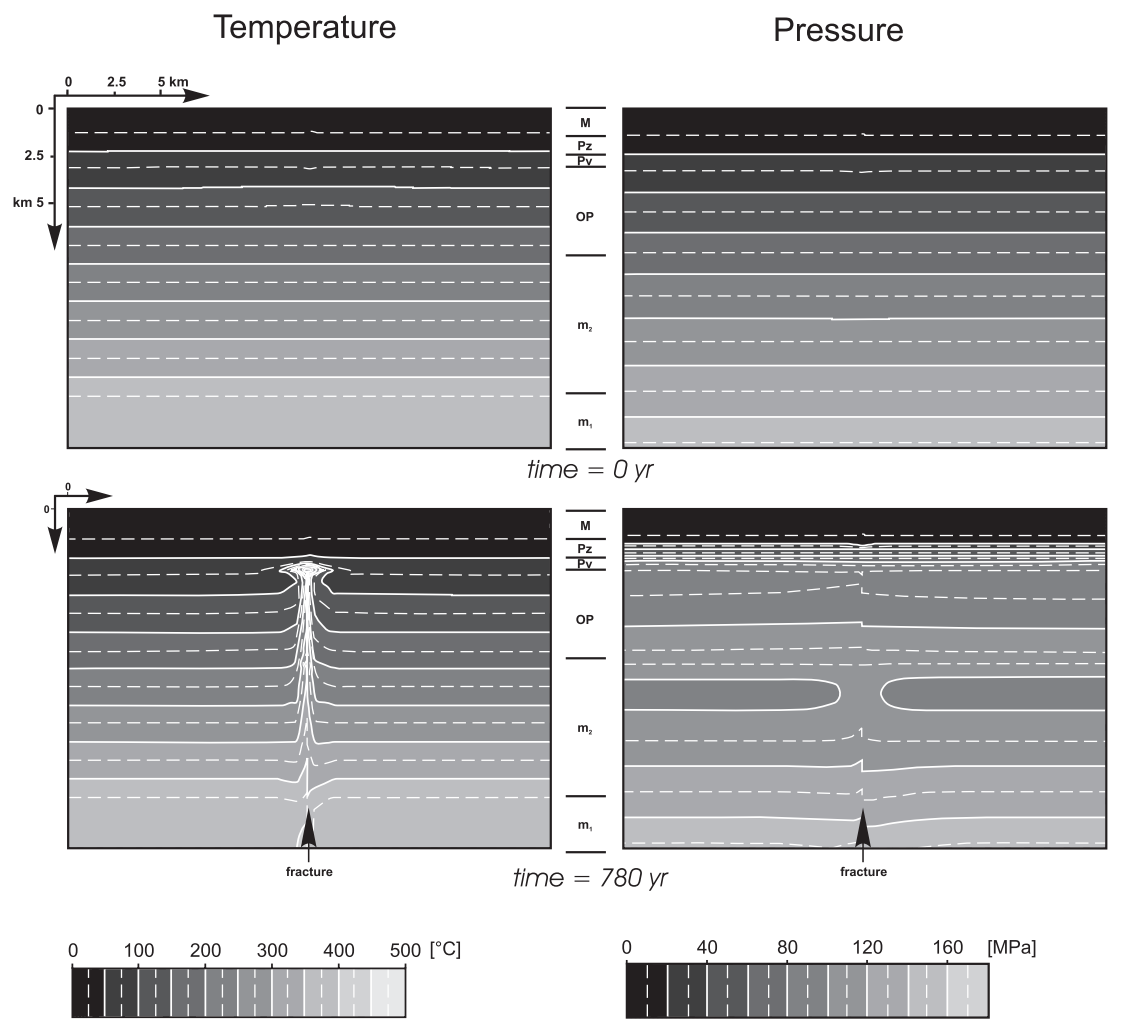

Fig. 19D. Computed pressure and temperature spatial distributions Fracture-flow model with hydraulically-open Permian volcanic layer (Pv); black arrow marks fracture inlet

is $c a 2.5 \mathrm{~km}$ wide. The fluid pressure distribution is uniform along layers within the upper $10 \mathrm{~km}$ thick zone. Model fluid pressures are significantly elevated reaching values comparable with lithostatic pressures. However, the model cannot fit the Witnica 1 points. This model appears to be applicable to Namyślin 1 and Dzieduszyce 1, but not Witnica 1.

The second model variation assumes that the Pv layer is separated from the older Palaeozoic layer (OP) by a thin sealing layer with low permeability $\left(10^{-19} \mathrm{~m}^{2}\right)$ and that incoming fluid is discharged through sinks symmetrically located at both ends of the Pv layer (Fig. 19E). The best fit is achieved with a two-stage flow-rate profile: Stage $1-$ $37.6 \mathrm{~kg} \cdot \mathrm{s}^{-1}$ over 112 years and Stage $2-45 \mathrm{~kg} \cdot \mathrm{s}^{-1}$ over 32 years (Fig. 18). The expected pressure and temperature in the Pv layer is reached after $c a 134$ years. The area of increased temperature is $c a 2.5 \mathrm{~km}$ wide - as in the first variation of this model. The fluid pressure distribution is uniform along layers within the Pv layer only. The model fluid pressures exceed the appropriate lithostatic pressure by half. However, cal- culations show that the model can fit the estimated metamorphic conditions very well with flow parameters as follows (Fig. 20):

1) Namyślin 1 - single stage flow at $38.3 \mathrm{~kg} \cdot \mathrm{s}^{-1}$ over 178 years, 


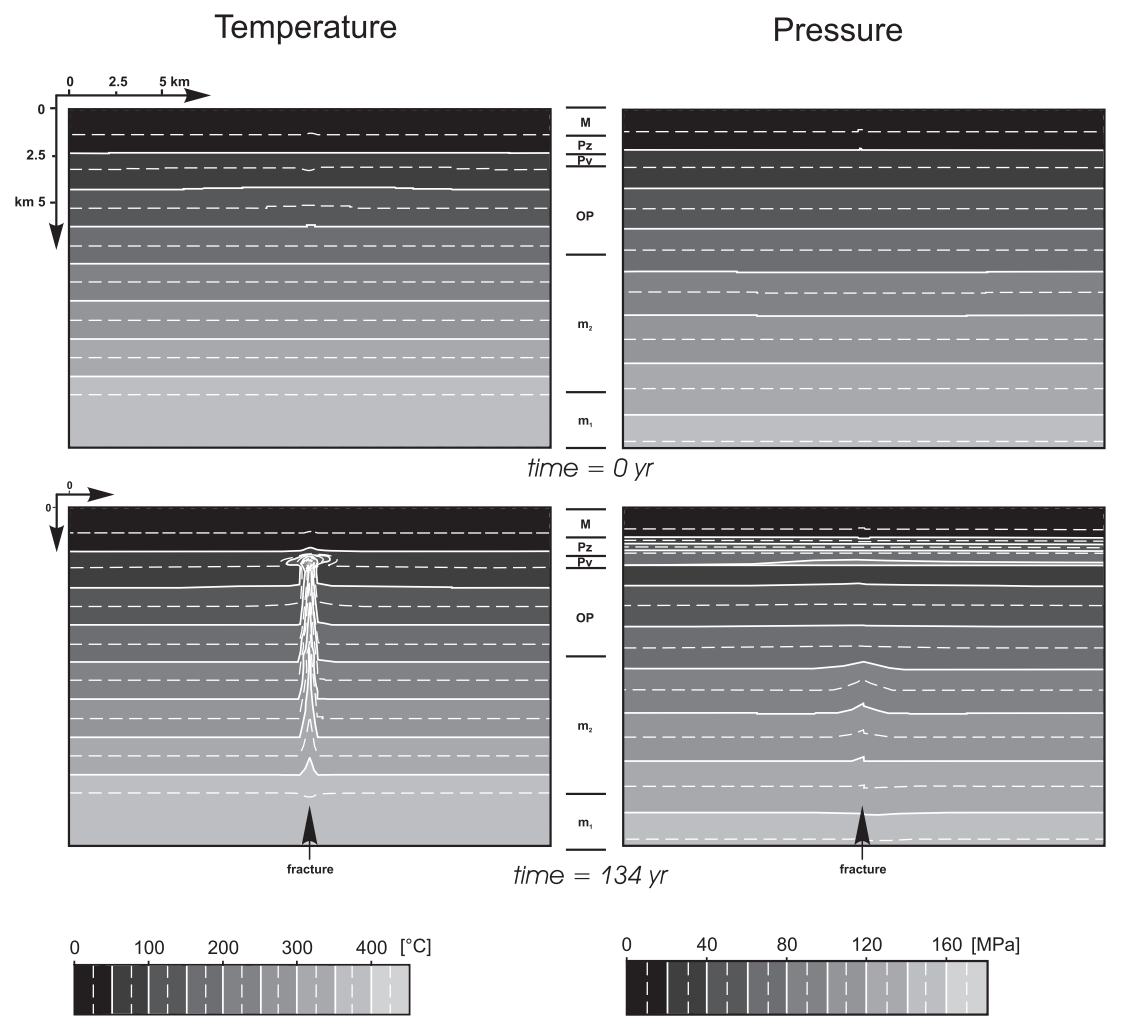

Fig. 19E. Computed pressure and temperature spatial distributions

Fracture-flow model with hydraulically-separated (limited permeability) Permian volcanic layer (Pv);

black arrow marks fracture inlet. See Table 5 for abbreviations

2) Witnica 1 - three flow stages. $1^{\text {st }}$ stage: $37.05 \mathrm{~kg} \cdot \mathrm{s}^{-1}$ over 193 years. $2^{\text {nd }}$ stage: $45 \mathrm{~kg} \cdot \mathrm{s}^{-1}$ over 21 years. $3^{\text {rd }}$ stage: $35.5 \mathrm{~kg} \cdot \mathrm{s}^{-1}$ over 24 years.

3) Dzieduszyce 1 - two flow stages. $1^{\text {st }}$ stage: $37.6 \mathrm{~kg} \cdot \mathrm{s}^{-1}$ over 112 years. $2^{\text {nd }}$ stage: $45 \mathrm{~kg} \cdot \mathrm{s}^{-1}$ over 32 years.

The calculated model flow rates lie within the range of values seen in the Wasatch Front in Utah, USA (Ehlers, Chapman 1999) and appear to be realistic. The numerical modelling leads to the conclusion that fracture-controlled, hydrothermal fluid flow through the Permian volcanic rocks was the most probable cause of alteration - that the observed metamorphism and metasomatism was the result of hydrothermal alteration. The calculations suggest relatively short geological time spans for the temperature and pressure changes as well as a restricted local range for any metamorphic alterations. The modelling also points to a prograde metamorphic process that was of short duration. Any rapid increase of temperature and pressure would imply that any large-scale equilibrium would be difficult to attain. Cui et al. (2003), however, have demonstrated the possibility of metamorphic mineral crystallization within hundreds of years where local fluid-rock equilibrium is attained. On the other hand, the duration of fluid-driven metamorphism might well be limited by decreasing permeability due to 


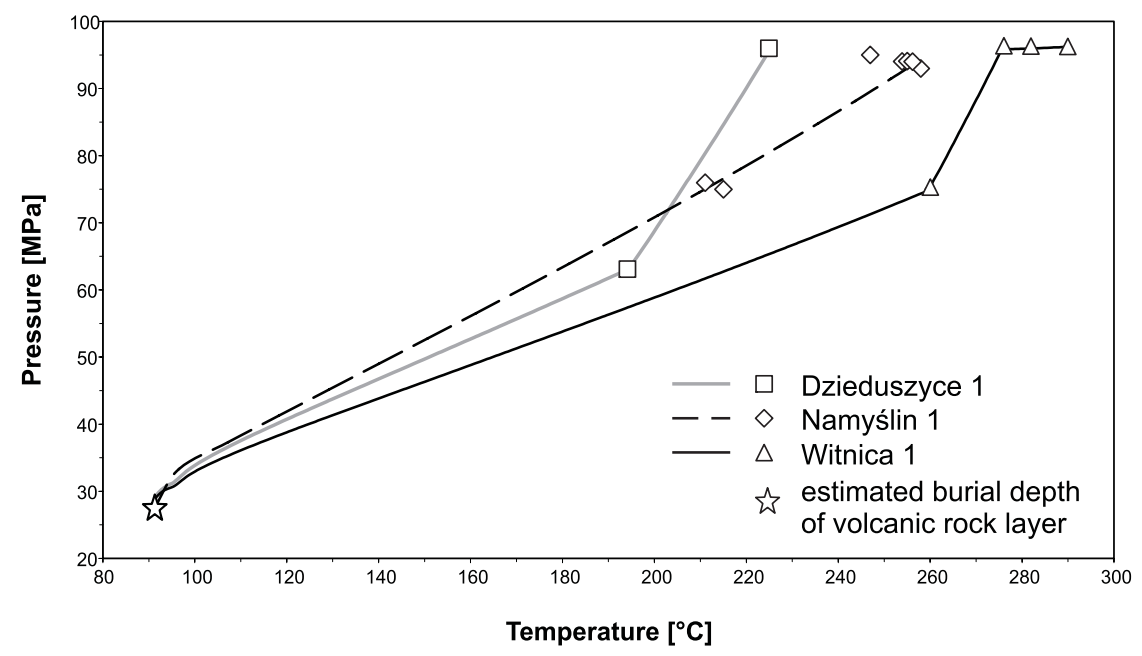

Fig. 20. Pressure vs. temperature trajectories computed on the basis of fracture-flow model with hydraulically separated Pv layer. All curves concern observation point located within upper central part of volcanic layer; data points refer to entrapment p-T conditions measured Dzieduszyce, Namyślin, and Witnica samples as well as estimated burial p-T conditions; inflow parameters: Dzieduszyce case two-stage flow: $1^{\text {st }}$ stage: $37.6 \mathrm{~kg} \cdot \mathrm{s}^{-1}$ during 112 years, $2^{\text {nd }}$ stage: $45 \mathrm{~kg} \cdot \mathrm{s}^{-1}$ during 32 years; Namyślin case - single stage flow: $38.3 \mathrm{~kg} \cdot \mathrm{s}^{-1}$ during 178 years,

Witnica case - three-stage flow: $1^{\text {st }}$ stage: $37.05 \mathrm{~kg} \cdot \mathrm{s}^{-1}$ during 193 years, $2^{\text {nd }}$ stage: $45 \mathrm{~kg} \cdot \mathrm{s}^{-1}$ during 21 years, $3^{\text {rd }}$ stage: $35.5 \mathrm{~kg} \cdot \mathrm{s}^{-1}$ during 24 years

the sealing of fractures and cracks. According to Brenan (1991 and references therein), fracture sealing by silica species can occur over intervals ranging from days to hundreds of years depending on physical and chemical conditions. Considering the limited longevity of fractures, and the results of Cui et al. (2003), the estimated duration of the metamorphism as modelled above (140-250 years) could well be plausible.

The calculated duration and rates of fluid flow suggest that the total mass of the hydrothermal fluid (assumed to be pure water) involved was ca $1.5-3 \cdot 10^{11} \mathrm{~kg}$. Connolly (1997 and references therein) estimated a time-averaged dehydration mass flux range of $2-8 \cdot 10^{-9} \mathrm{~kg} \cdot \mathrm{m}^{-2} \cdot \mathrm{s}^{-1}$ at the top of the metamorphic rock complex. If the hydrothermal activity studied was a result of devolatilization, the total mass released during the hydrothermal event could have been the generated through dehydration, over 4-16 ka, of $c a 100 \mathrm{~km}^{2}$ of the surface of the metamorphic rock complex. As Thompson (1997) noted, metamorphic fluids may be stored in natural reservoirs until released. These considerations and speculations suggest that the hydrothermal activity in the Gorzów Wielkopolski area might well have been the result of the focused discharge of metamorphic fluids from some deep retention reservoir during fault movement.

\section{Brecciation and hydraulic fracturing}

Hydraulic fracturing (or hydrofracturing) is a common and important geological process in many geological environments. It is "perhaps the most important single 
mechanism of deformation operative in the upper crust" (Fyfe et al. 1978). It generates the conduits controlling fluid release from reservoirs when the forces caused by the fluid pressure exceed the confining stress plus the modest tensile strength of the rock (e.g., Jaroszewski 1993; Flekkøy et al. 2002). The hydrothermal breccia is diagnostic of hydrofracturing. Clark and Jones (2003) show an example of brecciation related to fluid-assisted, fold-related faulting and that is also linked to low-grade metamorphism.

The brecciation of the volcanic rocks that are the subject of this paper, the cementation of the fragments by veinlets and the microscopic effects of crushing and brecciation all reflect an episode of intense fracturing. The vein-filling hydrothermal minerals, i.e., quartz, chalcedony and calcite, attest to hydraulic fracturing that occurred at a late stage in the metamorphic process.

The consistency of the maximum pressures obtained from the different samples suggests a critical limiting factor. Such might be tentatively recognised in the context of hydraulic fracturing. If the fluid pressure, which exceeded ca $94 \mathrm{MPa}$, overrode the critical tensile stress of the caprock (Flekkøy et al. 2002), the resulting drop in fluid pressure would have led to the loss of chemical equilibrium and, potentially, silica scaling. The sealed fractures would have blocked further inflow.

\section{SUMMARY AND CONCLUSIONS}

The preserved igneous textures and the abundant vesicles identify the mafic metavolcanic rocks from the Gorzów Wielkopolski area as surface extrusions. Geochemically, the rocks are andesite-basalts and andesites derived from a within-plate, subalkaline basalt melt. A new age of extrusion, $285 \pm 5 \mathrm{Ma}$, extends the time-range of Early Permian volcanic activity. The rocks from Gorzów Wielkopolski may be among the youngest Permo-Carboniferous volcanic rocks on the eastern margin of North German Basin.

Based on metamorphic-mineral stabilities and on fluid-inclusion entrapment temperatures and pressures, the alteration of the volcanic rocks in the Namyślin 1 and Dzieduszyce 1 boreholes is defined as a sub-greenschist facies metamorphism which took place within temperature and pressure ranges of $195-260^{\circ} \mathrm{C}$ and $63-96 \mathrm{MPa}$, respectively. Many of the metamorphic phases, e.g., corrensite, pumpellyite, laumontite and prehnite formed due to interaction between andesitic rock and low-saline, $\mathrm{Na}_{2} \mathrm{SO}_{4}$-rich fluid. A progressive change in fluid chemistry, including increasing salinity and $\mathrm{NaCl}$ content, suggests mixing of ascending fluids with Zechstein evaporate pore waters. Unusual p-T metamorphic conditions $\left(260-290^{\circ} \mathrm{C}\right.$ and $\left.75-96 \mathrm{MPa}\right)$ recognised in the Witnica 1 borehole can be explained as due to the rapid inflow of hot fluids containing $\mathrm{CO}_{2}$. Fluid pressure exceeding $\mathrm{ca} 94 \mathrm{MPa}$ caused caprock hydrofracturing that resulted in a drop in fluid pressure, a loss of chemical equilibrium and extensive scaling; fracture sealing that stopped further inflow.

K-Ar dating reveals three Mesozoic metamorphic events: 1) Aptian (121 $\pm 2 \mathrm{Ma})$ recognised in the Dzieduszyce 1 borehole, 2) Sinemurian-Pliensbachian (188-190 Ma)

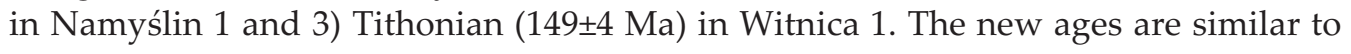


Mesozoic ages reported from altered volcanic and clastic rocks elsewhere in Germany and Poland.

The new metamorphic ages contribute to a reconstruction of the geological setting in which the metamorphic events took place. Taking stratigraphic data and an assumed hydrostatic pressure into account, the burial temperature and formation pressure is estimated to have been $85-92^{\circ} \mathrm{C}$ and $25-26 \mathrm{MPa}$, respectively. These values are considerably lower than the values deduced from observed metamorphic features. Numerical modelling results indicate that hydrothermal fluid flow through fractures is the most probable cause for the alteration of the rocks. The alteration process can be defined as fluid-driven low-grade metamorphism combined with metasomatism or as hydrothermal metamorphism. The modelling suggests a relatively rapid transfer of heat and fluid pressure from the lower crust lasting ca 140-250 years at least and, also, restriction of the metamorphic alteration to a limited area. Thus, the metamorphism was plausibly driven by the focused discharge of metamorphic fluids during fault activation with concomitant progressive contamination of the ascending metamorphic fluids by descending pore waters.

Acknowledgements. The author would like to thank Elżbieta Dubińska, Andrzej Kozłowski, Bogusław Bagiński, Grzegorz Kaproń, and Bożena Łącka for stimulating discussions and help during this study. Jacek Puziewicz and two anonymous reviewers are thanked for theirs thoughtful reviews. The author is indebted to Padhraig Kennan for critical review of manuscript and stylistic improvements. Piotr Dzierżanowski, Krzysztof Nejbert, Ryszard Orłowski, and Michał Kuźniarski are gratefully acknowledged for help during microprobe analysis, for remarkable BSE photos and element mappings as well as for X-ray diffractograms. The author would like to thank Dorota Bakowska and Michał Banaś for K-Ar determinations. The Ministry of Education and Science (former State Committee for Scientific Research; grant 6 P04D 014 09) and Institute of Geological Sciences PAS (grant 10.3/2004 and 4.3/2005) supported this research. Last but not least, the author is indebt to his wife, Katarzyna Delura, and his father, Andrzej Bylina, for their invaluable help, patience, and support.

\section{REFERENCES}

AWDANKIEWICZ M., 1999a: Volcanism in a late Variscan intramontane trough: Carboniferous and Permian volcanic centres of the Intra-Sudetic Basin, SW Poland. Geologia Sudetica 32, 13-47.

AWDANKIEWICZ M., 1999b: Volcanism in a late Variscan intramontane trough: the petrology and geochemistry of the Carboniferous and Permian volcanic rocks of the Intra-Sudetic Basin, SW Poland. Geologia Sudetica 32, 83-112.

BAKHT M.S., 2000: Borehole geology and hydrothermal alteration of well KJ-28 Krafla high-temperature area, NE Iceland. In: Proceedings of the World Geothermal Congress 2000, 947-952, Kyushu-Tohoku, Japan.

BEAUFORT D., PAPANAGIOTOU P., PARTIER P., TRAINEAU H., 1995: Les interstratifiés I-S et C-S dans les champs géothermiques actifs: sont-ils comparable à ceux des séries diagénétiques? Bulletin du Centre des Recherches, Exploration-Production, Elf - Aquitaine 19 (1), 267-291

BECHTEL A., ELLIOTT W.C., WAMPLER J.M., OSZCZEPALSKI S., 1999: Clay mineralogy, crystallinity, and K-Ar ages of illites within the Polish Zechstein basin: Implications for the age of Kupferschiefer mineralization. Economic Geology 94, 261-272.

BENEK R., KRAMER W., MC CANN T., SCHECK M., NEGENDANK J.F.W., KORICH D., HUEBSCHER H.-D., BAYER U., 1996: Permo-Carboniferous magmatism of the Northeast German Basin. Tectonophysics 266, 379-404. 
BEVINS R.E., ROBINSON D., ROWBOTHAM G., 1991: Compositional variations in mafic phyllosilicates from regional low-grade metabasites and application of the chlorite geothermometer. Journal of Metamorphic Geology 9, 711-721.

BLUNDELL D.J., KARNKOWSKI P.H., ALDERTON D.H.M., OSZCZEPALSKI S., KUCHA H., 2003: Copper mineralization of the Polish Kupferschifer: a proposed basement fault-fracture system of fluid flow. Economic Geology 98, 1487-1495.

BOLES J.R., COOMBS D.S., 1977: Zeolite-facies alteration of sandstones in the Southland syncline, New Zealand. American Journal of Science 277, 982-1012.

BONESS M., HAACK U., FELDMANN K.F., 1990: Rb/Sr Datierung der hydrothermalen Pb-Zn Vererzung von Bad Grund (Harz), BRD. Chemie der Erde 50, 125.

BRECHT G.A., 1999: Authigene Phyllosilicate in permokarbonen $\mathrm{SiO}_{2}$-reichen Vulkaniten Ostdeutschalands. Berliner geowissenschaftliche Abhhandlungen, Reihe A 201,1-181.

BRECHT G.A., BREITKREUTZ C., 1997: Hydrothermal phyllosilicates in Permian silica-rich volcanic rocks of eastern Germany. Terra Nostra 9 Abs. Suppl. 1, 575.

BRECHT G.A., WOLFGRAMM M., 1998: Mesozoic thermal activity in the NE-German basin recorded in authigenic phyllosilicates of Permocarboniferous $\mathrm{SiO}_{2}$-rich volcanic rocks. Scripta Facultatis Scientarium Naturalum Universitatis Masarykianć Brunensis Geology 26, 30-31.

BREITKREUZ C., KENNEDY A., 1999: Magmatic flare-up at the Carboniferous/Permian boundary in the German Basin revealed by SHRIMP zircon ages. Tectonics 302, 307-326.

BRENAN J.M., 1991: Development of metamorphic permeability: implications for fluid transport processes. Reviews in Mineralogy 26, 291-320.

BRINK H.-J., 2005: The evolution of the North German Basin and the metamorphism of the lower crust. International Journal of Earth Sciences 94, 1103-1116.

BUNIAK A., 2004: Mapa lokalizacji złóż węglowodorów w utworach dolomitu głównego. http://www.pgi.gov.pl/images/stories/ropa_Ca2_zloza.jpg, Państwowy Instytut Geologiczny, Warszawa.

BYLINA P., DUBIŃSKA E., KAPROŃ G., KOZUBOWSKI J.A., KOZŁOWSKI A., BAGIŃSKI B., KULICKI C., 2000: Corrensite from metavolcanic rocks near Gorzów Wielkopolski (NW Poland): its position in very low grade metamorphic assemblage. Mineralogical Society of Poland - Special Papers 17, 128-131.

CARR P.F., PEMBERTON J.W., NUNAN E., 1999: Low-grade metamorphism of mafic lavas, Upper Permian Broughton Formation, Sydney Basin. Australian Journal of Earth Sciences 46, 839-849

CHO M., LIOU J., 1987: Prehnite-pumpellyite to greenschist facies transition in the Karmutsen metabasites, Vancouver Island, B. C. Journal of Petrology 28, 417-443.

CLARK C., JONES P., 2003: Hydrothermal brecciation due to fluid pressure fluctuations: examples from the Oladry Domain, South Australia. Tectonophysics 366, 187-206.

CONNOLLY J.A.D., 1997: Mid-crustal focused fluid movement: thermal consequences and silica transport. In: Jamtveit B., Yardley B. (eds), Fluid Flow Transport in Rocks. Mechanisms and Effects, 235-250, Chapman Hall.

CORTESOGNO L., LUCCHETTI G., SPADEA P., 1984: Pumpellyite in low-grade metamorphic rocks from Ligurian and Lucanian Apennines, Maritime Alps and Calabria. Contributions to Mineralogy and Petrology $85,14-24$.

CUI X., NABELEK P.I., LIU M., 2003: Reactive flow of mixed $\mathrm{CO}_{2}-\mathrm{H}_{2} \mathrm{O}$ fluid and progress of calc-silicate reactions in contact metamorphic aureoles: insights from two-dimensional numerical modeling. Journal of Metamorphic Geology 21, 663-684.

CZECHOWSKI F., PIELA J., 1997: Skład molekularny substancji organicznej zawartej w dolomicie głównym oraz skałach wylewnych z otworu Namyślin-1. Nafta-Gaz 53, 299-308 (in Polish).

CZERNY J., MUSZYŃSKI M., 1997: Co-magmatism of the Permian volcanites of the Krzeszowice area in the light of petrochemical data. Mineralogia Polonica 28, 3-25.

CZERNY J., MUSZYŃSKI M., 2000: The current state of recognition of Upper Palaeozoic volcanites of the Cracow area. Mineralogical Society of Poland - Special Papers 17, 13-17. 
DADLEZ R., NARKIEWICZ M., STEVENSON R.A., VISSER M.T.M., VAN WEES J.-D., 1995: Tectonic evolution of the Mid-Polish Trough: modeling implications and significance for central European geology. Tectonophysics 252, 179-195.

DIGEL S.C., GORDON T.M., 1995: Phase relations in metabasites and pressure-temperature conditions at the prehnite-pumpellyite to greenschist facies transition, Flin Flon, Manitoba, Canada. In: Schiffman P., Day H.W. (eds), Low-Grade Metamorphism of Mafic Rocks, Geological Society of America Special Papers 296, 67-80, Geological Society of America.

DUBIŃSKA E., BAGIŃSKI B., KAPROŃ G., BYLINA P., 1998: Pumpellyit w zmienionych zasadowych skałach wulkanicznych z okolic Gorzowa Wielkopolskiego (północno-zachodnia część monokliny przedsudeckiej): przejawy metamorfizmu bardzo niskiego stopnia (VLGM). Przegląd Geologiczny 46, 71-79 (in Polish with English abstract).

DUBIŃSKA E., BYLINA P., BAGIŃSKI B., KAPROŃ G., KOZŁOWSKI A., 2004a: Geochemistry and mineralogy of Rotliegend metavolcanic mafic rocks from Poland: pervasive low-grade metamorphism versus parent rock signature. In: Wilson M., Neumann E.-R., Davies G.R., Timmerman M.J., Heeremans M., Larsen B.T. (eds), Permo-Carboniferous Magmatism and Rifting in Europe, Geological Society Special Publications 223, 393-413, The Geological Society of London.

DUBIŃSKA E., BYLINA P., KOZŁOWSKI A., DÖRR W., NEJBERT K., SCHASTOK J., KULICKI C., 2004b: $\mathrm{U}-\mathrm{Pb}$ dating of serpentinization: hydrothermal zircon from a metasomatic rodingite shell (Sudetic ophiolite, SW Poland). Chemical Geology 203, 183-203.

EHLERS T.A., CHAPMAN D.S., 1999: Normal fault thermal regimes: conductive and hydrothermal heat transfer surrounding the Wasatch fault, Utah. Tectonophysics 312, 217-234.

FLEKKØY E.G., MALTHE-SØRENSSEN A., JAMTVEIT B. 2002: Modeling hydrofracture. Journal of Geophysical Research - Solid Earth 107(B8), 2151, 1-11.

FOLAND K.A., 1994: Argon diffusion in feldspar. In: Parsons I. (ed.), Feldspars and Their Reactions, 415-447, Kluwer, Dordrecht.

FREY M., DE CAPITANI C., LIOU J.G., 1991: A new petrogenetic grid for low-grade metabasites. Journal of Metamorphic Geology 9, 497-509.

FRÜH-GREEN G.L., PLAS A., DELL'ANGELO L.N., 1996: Mineralogic and stable isotope record of polyphase alteration of upper crustal gabbros of the East Pacific Rise (Hess Deep, Site 894). Proceedings of the Ocean Drilling Program, Scientific Results 147, 235-254.

FYFE W.S., PRICE N., THOMPSON A.V., 1978: Fluids in the Earth's Crust. Elsevier Science, New York, $383 \mathrm{pp}$.

GIANELLI G., MEKURIA N., BATTAGLIA S., CHERSICLA A., GAROFALO P., RUGGIERI G., MANGANELLI M., GEBREGZIABHER Z., 1998: Water - rock interaction and hydrothermal mineral equilibria in the Tendaho geothermal system. Journal of Volcanology and Geothermal Research 86, 253-276.

GOLL M., LIPPOLT H.J., HOEFS J., 2003: Mezozoic alteration of Permian volcanic rocks (Thüringer Wald, Germany): Ar, Sr and O isotope evidence. Chemical Geology 199, 209-231.

GÓRNIAK K., GAWEŁ A., MUSZYŃSKI M., PROTAS A., RATAJCZAK T., SZYDŁAK T., 2004: Wpływ głębokości pogrzebania na proces illityzacji smektytu w czarnych łupkach dinantu z Pomorza Zachodniego. In: Protas A., Mikołajewski Z., Buniak A. (eds), Pozycja geologiczna i petrologia utworów podłoża permu w strefie Koszalin-Chojnice, 43-95, Bogucki Wydawnictwa Naukowe, Poznań (in Polish).

GREGOSIEWICZ Z., 1986: Wstępne wyniki dotychczasowych badań petrograficznych utworów podpermskich w zachodniej części Monokliny Przedsudeckiej. Nafta 42, 301-304 (in Polish).

GREGOSIEWICZ Z., 1990: Rozpoznanie petrograficzne utworów podpermskich we wschodniej części Monokliny Przedsudeckiej. Nafta 46, 54-60 (in Polish).

HAACK U.K., ZIMMERMANN H.D., 1996: Retrograde mineral reactions: a heat source in the continental crust? Geologische Rundschau 85, 130-137.

HAYBA D.O., INGEBRITSEN S.E., 1994: The computer model HYDROTHERM, a three-dimensional finite-difference model to simulate ground-water flow and heat transport in the temperature range of 0 to 1,200 degrees Celsius. U.S. Geological Survey Water-Resources Investigations, Report 94-4045, US Geological Survey, Reston (VA), 85 pp. 
HAYDUKIEWICZ J., MUSZER J., KŁAPCIŃSKI J., 1999: Dokumentacja paleontologiczna osadów podpermskich w rejonie Zbąszynia (Monoklina Przedsudecka). In: Muszer A. (ed.), Wybrane zagadnienia stratygrafii, tektoniki i okruszcowania Dolnego Śląska, 7-17, Wyd. Uniwersytetu Wrocławskiego, Wrocław (in Polish).

HEIJLEN W., MUCHEZ P., BANKS D.A., SCHNEIDER J., KUCHA H., KEPPENS E., 2003: Carbonate-hosted $\mathrm{Zn}-\mathrm{Pb}$ deposits in Upper Silesia, Poland: origin and evolution of mineralizing fluids and constraints on genetic models. Economic Geology 98, 911-932.

HERMAN Z., MAMCZUR S., 1986: Anomalnie wysokie ciśnienia złożowe w anhydrycie głównym cechsztynu. Nafta 42, 201-208 (in Polish).

HUEBSCHER H.-D., 1995: Zur epigenetischen Metasomatoze in der permosilesischen basaltischen Mg-andesiten von der Ost-Branderburg, Deutschland. Terra Nostra 7, 63-66.

HUENGES E., ERZINGER J., KÜCK J., ENGESER B., KESSELS W., 1997: The permeable crust: Geohydraulic properties down to $9101 \mathrm{~m}$ depth. Journal of Geophysical Research 102 (B8), 18255-18265.

JACKOWICZ E., 1994: Permskie skały wulkaniczne północnej części monokliny przedsudeckiej. Prace Państwowego Instytutu Geologicznego 145, 1-47 (in Polish).

JACKOWICZ E., 1995: Lower Rotliegend volcanic rocks from the western part of the Polish Lowland. Terra Nostra 7, 67-69.

JANIK T., YLINIEMI J., GRAD M., THYBO H., TIIRA T., POLONAISE P2 WORKING GROUP, 2002: Crustal structure across the TESZ along POLONAISE'97 seismic profile P2 in NW Poland. Tectonophysics 360, 129-152.

JAROSZEWSKI W., 1993: Manifestations of hydrotectonics in $\mathrm{Zn}-\mathrm{Pb}$ mineralization at Trzebionka mine (Silesian-Cracow zinc-lead ore district, Poland). Geological Quarterly 37, 241-254.

JENSEN S.L., JANIK T., THYBO H., POLONAISE PROFILE P1 WORKING GROUP, 1999: Seismic structure of the Palaeozoic Platform along POLONAISE'97 profile P1 in northwestern Poland. Tectonophysics 314, 123-143.

JOURDE H., FLODIN E. A., AYDIN A., DURLOFSKY L. J., WEN X.-H., 2002: Computing permeability of fault zones in eolian sandstone from outcrop measurements. AAPG Bulletin 86, 1187-1200.

JOVE C., HACKER R., 1997: Experimental investigation of laumontite $\rightarrow$ wairakite $+\mathrm{H}_{2} \mathrm{O}$ : a model diagenetic reaction. American Mineralogist 82, 782-789.

JUSKOWIAK-SCHOENEICHOWA M., 1979: Budowa geologiczna niecki szczecińskiej i bloku Gorzowa. Prace Instytutu Geologicznego 96, 1-178 (in Polish with English abstract).

KARNKOWSKI P.H., 1999: Origin and evolution of the Polish Rotliegend basin. Polish Geological Institute, Special Papers 3, 1-93.

KŁAPCIŃSKI J., JUROSZEK C., SACHANBIŃSKI M., 1988: Wulkanity dolnego permu północnej części monokliny przedsudeckiej. Acta Universitatis Wratislaviensis, Prace Geologiczno-Mineralogiczne 41, 3-31 (in Polish).

KŁAPCIŃSKI J., KARWOWSKI L., 1978: Fauna utworów cechsztyńskich w północnej części monokliny przedsudeckiej. Geologia Sudetica 13, 67-81 (in Polish with English abstract).

KOZŁOWSKA A., POPRAWA P., 2004: Datowanie K/Ar diagenetycznego illitu z piaskowców karbońskich obszaru mazowieckiego i ich znaczenie dla rekonstrukcji historii termicznej. In: Michalik M., Jacher-Śliwczyńska K., Skiba M., Michalik J. (eds), Datowanie Minerałów i Skał, VIII Ogólnopolska Sesja Naukowa, 18-19 listopada 2004, 64-68, Kraków, Poland (in Polish with English abstract).

KRZEMIŃSKI L., 2002: Pochodzenie materiału detrytycznego w karbońskich piaskowcach wschodniej części obszaru przedsudeckiego: petrografia i geochemia. Ph.D. thesis (manuscript), Polish Geological Institute, Warszawa, 1-143 (in Polish).

KRZYWIEC P., 2004: Triassic evolution of the Kłodawa salt structure: basement-controlled salt tectonics within the Mid-Polish Trough (Central Poland). Geological Quarterly 48, 123-134.

KUS J., CRAMER B., FOCKEL F., 2005: Effects of a Cretaceous structural inversion and postulated high heat flow event on petroleum system of the western Lower Saxony basin and the charge history of the Apeldorn gas field. Netherlands Journal of Geosciences 84, 3-24. 
LAMARCHE J., SCHECK-WENDEROTH M., 2005: 3D structural model of the Polish Basin. Tectonophysics 397, 73-91.

LIEWIG N., CLAUER N., 2000: K-Ar dating of varied microtextural illite in Permian gas reservoirs, northern Germany. Clay Minerals 35, 271-281.

LIOU J. G., MARUYAMA S., CHO M., 1985: Phase equilibria and mineral parageneses of metabasites in low-grade metamorphism. Mineralogical Magazine 49, 321-333.

LIOU J. G., MARUYAMA S., CHO M., 1987: Very low-grade metamorphism of volcanic and volcaniclastic rocks-mineral assemblages and mineral facies. In: Frey M. (ed.), Low Temperature Metamorphism. 59-113, Blackie, Glasgow and London.

LIPPOLT H.J., RACZEK I., SCHLEICHER H., 1982: Isotopenalter (40Ar/39Ar; Rb-Sr) eines Unteren Rotliegend-Biotits aus der Wrzesnia/Polen. Aufschluss 33, 13-25.

LOVERA, O.M., RICHTER, F.M., HARRISON, T.M., 1989: ${ }^{40} \mathrm{Ar} /{ }^{39} \mathrm{Ar}$ thermochronometry for slowly cooled samples having a distribution of diffusion domain sizes. Journal of Geophysical Research 94, 17917-17935.

MAGRI F., BAYER U., CLAUSNITZER V., JAHNKE C., DIERSCH H.-J., FUHRMANN J., MÖLLER P., PEKDEGER A., TESMER M., VOIGT H., 2005: Deep reaching fluid flow close to convective instability in the NE German basin - results from water chemistry and numerical modeling. Tectonophysics 397, $5-20$.

MAJOROWICZ J., 2004: Thermal lithosphere across the Trans-European Suture Zone in Poland. Geological Quarterly 48, 1-14.

MAJOROWICZ J., ČERMAK V., ŠAFANDA J., KRZYWIEC P., WRÓBLEWSKA M., GUTERCH A., GRAD M., 2003: Heat flow models across the Trans-European Suture Zone in the area of the POLONAISE 97 seismic experiment. Physics and Chemistry of the Earth 28, 375-391.

MALISZEWSKA A., 1997: Wiek K/Ar włóknistego illitu z piaskowców czerwonego spągowca Wielkopolski. In: Datowanie minerałów i skał. IV Ogólnopolska Sesja Naukowa, 50-55, UMCS, Lublin.

MALISZEWSKA A., KIERSNOWSKI H., JACKOWICZ E., 2003: Wulkanoklastyczne osady czerwonego spagowca dolnego na obszarze Wielkopolski. Prace Państwowego Instututu Geologicznego 179, 1-59 (in Polish with English abstract).

MANNING C.E., INGEBRITSEN S.E., 1999: Permeability of the continental crust: implications of geothermal data and metamorphic systems. Reviews of Geophysics 37, 127-150.

MAREK S., PAJCHLOWA M., 1997: Epikontynetalny perm i mezozoik w Polsce. Prace Państwowego Instytutu Geologicznego 153, 1-452 (in Polish with English abstract).

MARX J., HUEBSCHER H.-D., HOTH K., KORICH D., KRAMER W., 1995: Vulkanostratigraphie und Geochemie der Eruptivkomplexe. In: Plein E (ed.), Norddeutsches Rotliegendbecken - Rotliegend Monographie Teil II, 83, 54-83, Courier Forschungsinstitut Senkenberg.

MAZUR S., SCHECK-WENDEROTH M., KRZYWIEC P., 2005: Different modes of the Late Cretaceous-Early Tertiary inversion in the North German and Polish basins. International Journal of Earth Sciences 94, 782-798.

MCCANN T., 1996: The tectonosedimentary evolution of the northern margin of the Carboniferous basin of NE Germany. Tectonophysics 313, 119-144.

MICHALIK M., 2001: Diagenesis of the Weissliegend sandstones in the south-western margin of the Polish Rotliegend basin. Prace Mineralogiczne 91, 1-176.

MICHALIK M., BANAŚ M., SMOLAK W., 2004: Secondary minerals in the Lower Permian Filipowice tuff: a record of the Liassic hydrothermal event. Acta Mineralogica - Petrographica, Abstract Series 4, 72.

MICHALIK M., PĘKALA M., WÓJTOWICZ A., 2003: Alteration of Lower Permian volcanic rocks from SW part of Polish Rotliegend basin: clay minerals record of a long history. Book of Abstracts, Euroclay 2003, European Clay Conference, 190, Modena, Italy.

MIHALYNUK M.G., GHENT E.D., 1996: Regional depth-controlled hydrothermal metamorphism in the Zymoetz River area. British Columbia. Canadian Journal of Earth Sciences 33, 1169-1184.

NEUMANN E.-R., WILSON M., HEEREMANS M., SPENCER E.A., OBST K., TIMMERMANN M.J., KIRSTEIN L., 2004: Carboniferous-Permian rifting and magmatism in southern Scandinavia, the North Sea and northern Germany: A review. In: M. Wilson E.-R., Neumann G.R., Davies M.J., Timmerman M., 
Heeremans M., Larsen B.T. (eds), Permo-Carboniferous Magmatism and Rifting in Europe, Geological Society Special Publications, 223, 11-40, The Geological Society of London.

NOURALIEE J., 2000: Borehole geology and hydrothermal alteration of well NJ-20, Nesjavellir high-temperature area, SW Iceland. United Nations University Geothermal Training Programme, Report 15, 303-330, Iceland.

OLIVER N.H.S., 2001: Linking of regional and local hydrothermal systems in the mid-crust by shearing and faulting. Tectonophysics 335, 147-161.

OSZCZEPALSKI S., 1999: Wiek mineralizacji cechsztyńskiej w świetle radiometrycznych badań illitu metodą K-Ar. In: Muszer A. (ed.), Wybrane zagadnienia stratygrafii, tektoniki i okruszcowania Dolnego Śląska, 75-84, Wyd. Uniwersytetu Wrocławskiego, Wrocław (in Polish).

PAULICK H., BREITKREUZ C., 2005: The Late Paleozoic felsic lava-dominated large igneous province in northeast Germany: volcanic facies analysis based on drill cores. International Journal of Earth Sciences 94, 834-850.

PLEIN E. 1993: Bemerkungen zum Ablaluf der paläogeographischen Entwicklung im Stefan und Rotliegend des Norddeutschen Beckens. Geologische Jahrbuch A131, 99-116.

POLYANSKY O.P., REVERDATTO V.V., KHOMENKO A.V., KUZNETSOVA E.N., 2003: Modeling of fluid flow and heat transfer induced by basaltic near-surface magmatism in the Lena-Tunguska petroleum basin (Eastern Siberia, Russia). Journal of Geochemical Exploration 78-79, 687-692.

PROTAS A., 2004: Wstępna ocena wyników badań izotopowych tufów dolnokarbońskich w strefie Koszalin-Chojnice. In: Protas A., Mikołajewski Z., Buniak A. (eds), Pozycja geologiczna i petrologia utworów podłoża permu w strefie Koszalin-Chojnice, 123-128, Bogucki Wydawnictwa Naukowe, Poznań, (in Polish).

RIEKE H., MCCANN T., KRAWCZYK C.M., NEGENDANK J.F.W., 2003: Evaluation of controlling factors on facies distribution and evolution in an arid continental environment: an example from the Rotliegend of the NE German Basin. The Geological Society of London Special Publications 208, 71-94.

ROEDDER E., 1984: Fluid inclusions. Reviews in Mineralogy 12, 1-644.

RYKA W., 1981: Some problems of the Autunian volcanism in Poland. In: International Symposium “Central European Permian", Warsaw 1978, 165-179, Geological Institute, Warszawa.

SADOWSKI K., MADEJ S., 2001: Petrography of mafic rocks from the Kotusz-1 borehole (northern part of Fore-Sudetic Monocline). Mineralogical Society of Poland - Special Papers 18, 180-185.

SCHECK M., BAYER U., 1999: Evolution of the Northeast German Basin - inferences from a 3D structural model and subsidence analysis. Tectonophysics 313, 145-169.

SCHECK-WENDEROTH M., LAMARCHE J., 2005: Crustal memory and basin evolution in the Central European Basin System - new insights from a 3D structural model. Tectonophysics 397, 143-165.

SCHIFFMAN P., DAY H.W., 1999: Petrological methods for the study of very low-grade metabasites. In: Frey M., Robinson D. (eds), Low-Grade Metamorphism, 108-142, Blackwell Science Ltd.

SCHIFFMAN P., FRIDLEIFSSON G.O., 1991: The smectite - chlorite transition in drillhole NJ-15, Nesjavellir geothermal field, Iceland: XRD, BSE, and electron microprobe investigations. Journal of Metamorphic Geology 9, 679-696.

SCHIFFMAN P., LIOU J.G., 1980: Synthesis and stability relations of Mg-Al pumpellyite, $\mathrm{Ca}_{4} \mathrm{Al}_{5} \mathrm{MgSi}_{6} \mathrm{O}_{21}(\mathrm{OH})_{7}$. Journal of Petrology 21, 441-474.

SCHIFFMAN P., SOUTHARD R.J., 1996: Cation exchange capacity of layer silicates and palagonitized glass in mafic volcanic rocks: A comparative study of bulk extraction and in situ techniques. Clays and Clay Minerals 44, 624-634.

SCHMIDT-MUMM A., WOLFGRAMM M., 2002: Diagenesis and fluid mobilization during the evolution of the North German Basin - evidence from fluid inclusion and sulphur isotope analysis. Marine and Petroleum Geology 19, 229-246.

SCHMIDT-MUMM A., WOLFGRAMM M., 2004: Fluid systems and mineralization in the north German and Polish basin. Geofluids 4, 315-328.

SCHNEIDER J., GEBHARDT U., 1993: Litho- und Biofaziesmuster in intra- und extramontanen Senken des Rotliegend (Perm, Nord und Ostdeutschland). Geologische Jahrbuch A131, 57-98. 
SCHNEIDER J., HAACK U., STEDINGK K., 2003: Rb-Sr dating of epithermal vein mineralization stages in the eastern Harz Mountains (Germany) by paleomixing lines. Geochimica et Cosmochimica Acta 67, 1803-1819.

SHMONOV V.M., VITOVTOVA V. M., ZHARIKOV A.V., GRAFCHIKOV A.A., 2002: Fluid permeability of the continental crust: Estimation from Experimental Data. Geochemistry International 40 Suppl.1, 3-13.

SIEMASZKO E., 1978: Permskie skały wylewne w południowo-zachodniej części monokliny przedsuckiej. Kwartalnik Geologiczny 22, 571-584 (in Polish).

SIEMASZKO E., 1981: Autunian intrusives in the Fore-Sudetic Monocline. In: International Symposium “Central European Permian", Warsaw 1978, 201-211, Geological Institute, Warszawa.

SMITH R.E., WILTSCHKO D.V., 1996: Generation and maintenance of abnormal fluid pressures beneath a rampling thrust sheet: isotropic permeability experiments. Journal of Structural Geology 18, 951-970.

SPECZIK S., RYDZEWSKI A., 1983: Postmagmatic processes in Lower Permian volcanic rocks associated with the Żary pericline, south-western Poland. Archiwum Mineralogiczne 39, 79-91.

STEIGER R.H., JÄGER E., 1977: Subcommision on geochronology: convention on the use of decay constants in geo- and cosmochronology. Earth and Planetary Sciences Letters 36, 359-362.

STEINER A., 1977: The Wairakei geothermal area, North Island, New Zealand. New Zeland Geological Survey Bulletin 90, 1-136.

STEPHENSON R.A., NARKIEWICZ M., DADLEZ R., VAN WEES J.-D., ANDRIESSEN P., 2003: Tectonic subsidence modeling of the Polish Basin in the light of new data on crustal structure and magnitude of inversion. Sedimentary Geology 156, 59-70.

TEAGLE D.A.H., ALT J.C., BACH W., HALLIDAY A.N., ERZINGER J., 1996: Alteration of the upper ocean crust in a ridge-flank hydrothermal upflow zone: mineral, chemical, and isotopic constrains from Hole 896A. Proceedings of the Ocean Drilling Program, Scientific Report 148, 119-150.

TEKLEMARIAM M., BATTAGLIA S., GIANELLI G., RUGGIERI G., 1996: Hydrothermal alteration in the Aluto-Langano geothermal field, Ethiopia. Geothermics 25, 679-702.

THOMPSON A.B., 1997: Flow and focusing of metamorphic fluids. In: Jamtveit B., Yardley B. (eds), Fluid Flow Transport in Rocks. Mechanisms and Effects. 297-314, Chapman Hall.

TOMASSÓN J., KRISTMANNSDÓTTIR H., 1972: High temperature alteration minerals and thermal brines, Reykjanes, Iceland. Contributions to Mineralogy and Petrology 36,123-134.

VOSTEEN H.-D., RATH V., SCHMIDT-MUMM A., CLAUSER C. 2004 The thermal regime of the Northeastern German Basin from 2-D inversion. Tectonophysics 386, 81-95.

WANGEN M., MUNZ I.A., 2004: Formation of quartz veins by local dissolution and transport of silica. Chemical Geology 209, 179-192.

WIERZCHOWSKA-KICUŁOWA K., 1984: Budowa geologiczna utworów podpermskich monokliny przedsudeckiej. Geologia Sudetica 19,121-142.

WINCHESTER J.A., FLOYD P.A., 1977: Geochemical discrimination of different magma series and their differentiation products using immobile elements. Chemical Geology 20, 325-343.

WINCHESTER J.A., THE PACE TMR NETWORK TEAM, 2003: Palaeozoic amalgamation of Central Europe: new results from recent geological and geophysical investigations. Tectonophysics 360, 5-21.

WISIAN K.W., BLACKWELL D.D., 2004: Numerical modeling of Basin and Range geothermal systems. Geothermics 33, 713-741.

ZIEGLER P.A., 2005: Europe - Permian to Recent Evolution. In: Encyclopedia of Geology, 102-125, Elsevier Ltd.

ZWINGMANN H., CLAUER N., GAUPP R., 1999: Structure-related geochemical (REE) and isotopic characteristics of clay minerals from Rotliegend sandstone reservoirs (Permian, northern Germany). Geochimica et Cosmochimica Acta 63, 2805-2823.

ŻELAŹNIEWICZ A., MARHEINE D., OBERC-DZIEDZIC T., 2003: A late Tournaisian synmetamorphic folding and thrusting in the eastern Variscan foreland: ${ }^{40} \mathrm{Ar} /{ }^{39} \mathrm{Ar}$ evidence from the phyllites of the Wolsztyn-Leszno High, western Poland. International Journal of Earth Sciences 92, 185-194. 
Pawet BYLINA

\title{
PROCESY METAMORFICZNE NISKIEGO STOPNIA PERMSKICH SKA€ MAFICZNYCH Z BLOKU GORZOWA WIELKOPOLSKIEGO (MONOKLINA PRZEDSUDECKA, POLSKA PÓŁNOCNO-ZACHODNIA): WIEK I MECHANIZM PROCESU
}

\author{
Streszczenie
}

Zmienione skały wulkaniczne występujące w okolicach Gorzowa Wielkopolskiego są andezytami i andezytobazaltami, które powstały ze stopu właściwego dla subalkalicznych bazaltów wewnątrzpłytowych zanieczyszczonego materiałem skorupowym. Datowanie izotopowe pierwotnych skaleni potasowych metodą K-Ar określiło wiek erupcji na $285 \pm 5$ Ma. Otrzymany wiek sugeruje, że skały te mogą być najmłodszymi permokarbońskimi skałami wulkanicznymi z dotychczas badanych na wschodnim brzegu Basenu Północnoniemieckiego.

Petrologia skał z okolic Gorzowa Wlkp. oraz wyniki badań inkluzji fluidalnych $\mathrm{w}$ minerałach wskazują na proces metamorficzny odpowiadający warunkom facji subzieleńcowej (f. prehnitowo-pumpellyitowej). Proces ten przebiegał $\mathrm{w}$ temperaturach od 195 do $290^{\circ} \mathrm{C}$ i przy ciśnieniach od 63 do $96 \mathrm{MPa}$. Główne minerały metamorficzne, tj. corrensyt, pumpellyit, laumontyt i prehnit, krystalizowały w wymienionym zakresie warunków $\mathrm{p}-\mathrm{T}, \mathrm{w}$ wyniku reakcji zachodzącej pomiędzy skałą macierzystą i słabo zasolonymi roztworami hydrotermalnymi zawierającymi $\mathrm{Na}_{2} \mathrm{SO}_{4}$. $\mathrm{Na}$ podstawie wyników modelowania numerycznego wskazano na szczelinowy przepływ roztworów hydrotermalnych jako najbardziej prawdopodobną przyczynę obserwowanego procesu metamorficznego. Obliczenia sugerują też krótki czas trwania tego procesu: od 140 do 250 lat. Datowania izotopowe metodą K-Ar ujawniły istnienie trzech mezozoicznych epizodów metamorficznych związanych $\mathrm{z}$ badanym procesem, które miały miejsce 188-190 Ma, 149 $\pm 4 \mathrm{Ma} \mathrm{i} \mathrm{121 \pm 2} \mathrm{Ma.} \mathrm{Wieki} \mathrm{te} \mathrm{są} \mathrm{podobne} \mathrm{do} \mathrm{innych}$ mezozoicznych dat izotopowych otrzymanych ze zmienionych skał wulkanicznych i klastycznych, występujących w Basenie Polskim i Północnoniemieckim. 